\title{
"REMANSOS DE ENSUEÑO." LAS HUERTAS Y LA GESTIÓN DEL AGUA EN AGUASCALIENTES, 1855-1914
}

\author{
Jesús Gómez Serrano \\ Universidad Autónoma de Aguascalientes
}

La urbe triste, odalisca indolente reclinada en el valle, en el pensil de sus huertas [...]

Eduardo J. Correa, Un viaje a Termápolis, p. 153.

INTRODUCCIÓN

To mismo que en otras ciudades del país, en AguascalienLtes las huertas fueron parte orgánica del paisaje urbano a lo largo de toda la época colonial y el siglo xix. En Puebla el cabildo dispuso la formación de huertas sembradas de viña y arboleda, "base primaria de la subsistencia del vecindario"; entre 1534 y 1546 cuatro mandatos municipales alentaron la formación de "la cuenca hortelana" de la ciudad. ${ }^{1}$

Fecha de recepción: 2 de abril de 2014

Fecha de aceptación: 19 de junio de 2014

${ }^{1}$ Carabarín Gracia, Agua y confort, pp. 35-40. 
En Zacatecas, a pesar de la escasez de agua, se formaron desde fines del siglo xvi "grandes huertas" en las cercanías de la ciudad que la abastecían de frutas de Castilla, "hortalizas, verduras y legumbres de todos géneros". ${ }^{2}$ En Jerez había muchas, algunas de las cuales contaban con mercedes de agua del río Grande; en 1644, previniendo los abusos de los labradores, el oidor Cristóbal de Torres mercedó a los vecinos de la villa dos surcos de agua que debían repartirse precisamente entre "las casas y huertas de la vecindad". ${ }^{3}$ Estas huertas se fundieron en el paisaje jerezano, como lo sugiere el hecho de que en la época porfiriana se contaban por lo menos 22, "famosas por sus frutos" y sus plantas ornamentales, que formaban “jardines" en los traspatios. ${ }^{4}$ En Querétaro las huertas "daban un toque de color" y proveían al mercado local de diversas frutas y verduras; el crecimiento de la población determinó que las huertas se alejaran del centro de la ciudad y se dificultara su acceso al agua. ${ }^{5}$ En Uruapan, la feracidad del terreno permitió que se formaran huertas "de todas frutas $[\ldots]$ con tan linda disposición y arte que todo el pueblo parece un país flamenco, de frutales tan levantados, que en competencia de los pinos, se suben al cielo". ${ }^{6}$ Tacámbaro fue descrito como "el pueblo más hermoso de arboleda y fres-

2 Bakewell, Minería y sociedad, p. 109.

3 Berumen Félix, "Administración de aguas para riego", pp. 76-78, 81-82.

${ }^{4}$ Lira Vásquez, Una cindad ilustrada y liberal. Jerez en el Porfiriato, citado por SÁnchez Rodríguez y Alfaro Rodríguez, "Notas para la historia de la horticultura y el autoabasto urbano en México", p. 133.

${ }^{5}$ Super, La vida en Querétaro durante la Colonia, p. 30.

${ }^{6}$ SÁnchez Rodríguez, "Los pueblos huerteros de la cuenca del Tepalcatepec", p. 219; Sánchez Rodríguez y Boenm Schoendube, Cartografía hidráulica de Michoacán, pp. 165-166. 
co de rosas [...] porque no hay casa que no tenga una huerta grande, y en ella muchos naranjos, limones, cidras y muchos árboles frutales de tierra caliente". ${ }^{7}$ En Orizaba, los barrios de la periferia estaban ocupados casi por completo por huertas que se regaban con agua de los arroyos; "el casco urbano propiamente dicho estaba rodeado a los cuatro vientos de un cinturón hortícola”. En 1864 Manuel Payno observó que las huertas no tenían "muros de piedra mal pintados con cal”, sino arbustos de café, "naranjos cargados de frutos de oro", plátanos que se balanceaban "voluptuosamente” y bejucos que formaban "unos muros floridos por encima de los cuales aparecen las copas de otros árboles más corpulentos”. ${ }^{8} \mathrm{En}$ una escala mayor y más compleja puede citarse el ejemplo de los pueblos asentados en las riberas de los lagos de Texcoco, Chalco y Xochimilco, que abastecían de pescado fresco, verduras, frutas, artesanías, sal y flores a la ciudad de México. ${ }^{9}$

En la época de la ocupación musulmana, muchas ciudades peninsulares habían contado con numerosas y bien cultivadas huertas. Almería, por ejemplo, conservaba en el siglo Xvi un extenso alfoz en las inmediaciones de la muralla, más de 75 huertas, que en algunos casos contaban con torre, casa y norias o albercas; en su mayoría eran "pequeños huertos" que medían menos de una tahúlla, pero había algunas que medían 20 o más tahúllas y además estaban cercadas, constituyendo verdaderos jardines a los que sus propietarios se retiraban una vez "terminados sus quehaceres en la ciudad".

\footnotetext{
7 Fray Diego de Basalenque, citado por Sánchez Rodríguez y BoEHM Schoendube, Cartografía hidráulica de Michoacán, p. 160.

8 Ribera Carbó, Herencia colonial y modernidad burguesa, pp. 118-121; la cita de Payno procede de la p. 170.

9 Castillo Palma, Cuando la ciudad llegó a mi puerta, pp. 96-114.
} 
Esta cuenca hortelana, como dice Segura del Pino, constituía a la vez "un lugar de esparcimiento y una fuente de riqueza y de abastecimiento" para la ciudad. ${ }^{10}$

Lo mismo que tantas otras instituciones de la vida económica y social peninsular, la cultura hortícola echó raíces en la Nueva España y en toda la América española, aunque con resultados muy desiguales. Santiago de Chile, en el extremo sur del continente, a principios del siglo xviII era "todo él un vergel" que abastecía holgadamente a sus habitantes de "todos los productos del campo en frutas y legumbres", sin contar "los suaves olores de los naranjos [...] que embalsaman las casas". ${ }^{11}$ En España había una distinción clara entre la huerta, entendida como "el espacio dedicado al cultivo de hortalizas y árboles frutales" o bien el "conjunto de huertas o pequeñas propiedades situadas a inmediaciones de la ciudad y distribuidas de acuerdo con la red de canales o acequias de riego", y el huerto o huerto de traspatio, que designaba el espacio que "dentro de la casa" se cultivaba con árboles frutales "para recreo" y hortalizas y legumbres para el consumo familiar. En la América española esta "distinción tan tajante entre huerta y huerto" se diluyó en favor de un modelo híbrido en el que la huerta ya no era ajena al núcleo habitado, sino algo orgánicamente integrado al paisaje urbano. En todos lados el modelo español combinó el cultivo de los frutos de Castilla (árboles frutales y hortalizas) con productos típicamente americanos, como el cacao, la palma o

10 Segura del Pino, Agua, tierra y sociedad en el río de Almería, pp. 46-49. La tahúlla es una antigua medida agraria equivalente a $1118 \mathrm{~m}^{2}$.

11 Apuntes del viajero francés Amadeo Francisco Frezier citados por SÁnchez Rodríguez y Alfaro Rodríguez, "Notas para la historia de la horticultura”, p. 124. 
el café. ${ }^{12}$ Un buen ejemplo de mestizaje lo proporciona la cultura hortícola tlaxcalteca, de suyo compleja "en términos botánicos y productivos", que fue fecundada por la agricultura europea y se convirtió sin duda en una de las armas empleadas en la colonización del norte novohispano a partir de $1591 .^{13}$

En un artículo reciente, Martín Sánchez y Evelyn Alfaro han propuesto una revaloración de los huertos urbanos, centrada en el hecho de que permitían a las ciudades producir "alimentos de tipo animal y vegetal en los espacios domésticos", una variable crucial del abasto habitualmente despreciada "y mucho menos contabilizada en los estudios sobre el mercado urbano”. En Egipto, Grecia, Roma, Sudáfrica, Mesoamérica y muchos otros lugares la arqueología ha puesto en evidencia la existencia de gran diversidad de prácticas hortícolas, arraigadas de tal forma que fueron capaces de adaptarse a "todos los cambios" políticos, sociales y económicos experimentados por las sociedades. La horticultura se practicó de manera sistemática en muchas ciudades hasta que fue liquidada por "el crecimiento poblacional, la redefinición de espacios al interior de las casas, las ideas higienistas y las políticas de modernización en su conjunto". ${ }^{14}$

Este trabajo propone una caracterización del sistema de huertas de la ciudad de Aguascalientes, que fue muy importante desde el temprano siglo xvII hasta mediados del xx, cuando acabaron "engullidas por el progreso", es decir, arrasadas

12 Sánchez Rodríguez y Boenm Schoendube, Cartografía hidráulica de Michoacán, pp. 159-160.

${ }^{13}$ Martínez Saldaña, La diáspora tlaxcalteca, pp. 107, 113.

14 Sánchez Rodríguez y Alfaro Rodríguez, "Notas para la historia de la horticultura", pp. 117-118. 
por la industrialización salvaje, la explosión demográfica y la consiguiente expansión acelerada de la bien llamada "mancha urbana". La evidencia disponible sugiere que en Aguascalientes las huertas tuvieron un peso específico mayor del que tenían en otros centros urbanos, lo cual explicaría la expresión de Correa, que vio en ellas "algo típico" del lugar. ${ }^{15}$ Considérese tan sólo que en la década de 1880 había 459 con derecho a riego, 20 veces más de las que hacían la fama de Jerez. Se ha lamentado la dispersión y parquedad de "las fuentes para el estudio de los huertos como elementos característicos del espacio urbano", ${ }^{16}$ pero una revisión cuidadosa de los archivos locales en Aguascalientes nos ha deparado grandes sorpresas, cientos de documentos que sustentan nuestra descripción del sistema de riego, la evolución de los barrios-huerto, las tensiones nunca resueltas entre el espacio cultivado (las huertas) y el espacio habitado ("la ciudad"), el peso de la horticultura en las finanzas locales, la formación de un auténtico "cinturón de esmeralda" alrededor de la ciudad, etc. Es de suponer que en otros lugares en los que la práctica de la horticultura tuvo también gran importancia, los archivos conservan información que haría posible su caracterización, lo que nos permitiría avanzar por la senda de los estudios comparados.

\section{EL NOVELISTA Y EL CARTÓGRAFO}

El cartógrafo alemán Isidoro Epstein, a quien el azar o las revoluciones de 1848 llevaron a México, dibujó en 1855 el

15 Correa, Un viaje a Termápolis, p. 127.

16 Sánchez Rodríguez y Alfaro Rodríguez, "Notas para la historia de la horticultura”, p. 121. 
"Plano de las huertas de Aguascalientes", en realidad el primer mapa moderno de la ciudad conocido, que incluye 10 iglesias y conventos, 11 "edificios notables" y siete plazas, además de indicar el nombre de la mayor parte de las calles y el curso de los accidentes naturales más importantes. Por el este el límite de la mancha urbana eran los baños de Los Arquitos, mientras que por el oeste las huertas que estaban a espaldas del jardín de San Marcos, en tierras del antiguo pueblo de indios, formaban una línea casi recta. Por el norte el límite estaba definido por el Estanque y a su lado la garita de Zacatecas, mientras que por el sur el arroyo del Cedazo estaba rebasado por algunas huertas. A partir de este mapa puede calcularse que la superficie de la ciudad era de 550 hectáreas. ${ }^{17}$

El viejo casco urbano formaba un rectángulo limitado por el arroyo del Cedazo (sur), las calles de la Unión, el Terror y el Estío (norte), la calle del Olivo (este) y el jardín de San Marcos (oeste). Era la zona más densamente poblada de la ciudad, un perímetro dentro del cual había menos huertas. El barrio de San Marcos, el segundo más antiguo de la ciudad, figuraba en el mapa de Epstein como un extenso plantío apenas contrapesado por el jardín y el templo. En Triana coexistían las huertas y las zonas habitadas; el espacio se disputaba entre ambas y se puede apreciar que las huertas habían sido

${ }_{17}$ El original se conserva en la MOB, núm. 1689-25. Se publicó por primera vez, según la copia que hizo el señor Enrique Popoca, en El Unicornio, suplemento cultural del diario El Sol del Centro, 26 (13 mayo 1984), pp. 2-3. Se reprodujo en Orozco y Berra, Materiales para una cartografía mexicana, p. 120. Sobre Epstein puede consultarse el libro de Krause, Los judios en México; sobre sus actividades en Aguascalientes, Gómez Serrano, "Isidoro Epstein y la difusión del positivismo en México", pp. 112-118. 
desplazadas al extrarradio (el barrio de La Salud, que todavía no se conocía por ese nombre) y que la parte habitada formaba una unidad física con el casco histórico, aunque partida por el arroyo. Por el noreste, a un lado y otro de la acequia alimentada por el desagüe de los baños de Los Arquitos y que descargaba en el Estanque, sólo había huertas; era el barrio de Texas, que se formó a fines del xviII, cuando se construyó el Estanque y que todavía no resentía, como Triana, el embate de la urbanización. Finalmente, por el noroeste, estaba el barrio de Guadalupe, que tenía un carácter embrionario; con toda probabilidad, la dificultad de llevar el agua hasta allá impidió el desarrollo de huertas y las casas todavía no alcanzaban a definir manzanas propiamente dichas más que en las inmediaciones del templo y el camposanto.

Epstein dibujó con color verde "las huertas que reciben el agua de Ojocaliente" y con amarillo las que no tenían ese beneficio. El empleo de esos colores vuelve más fácilmente apreciable el peso que tenían las huertas en la ciudad, su desigual reparto en cada barrio y la forma en que determinaban el tejido urbano. En total, las huertas ocupaban unas 210 ha, de las cuales 150 se regaban con agua de Ojocaliente. Si la ciudad ocupaba una superficie de 550 ha, podemos decir que casi $40 \%$ correspondía a sus huertas, lo que nos habla de su masiva presencia y de la razón por la cual Epstein llamó plano de las huertas lo que en rigor era un plano de la ciudad. Esto puede interpretarse como una sugestiva concesión a la importancia que tenían las huertas en la vida de la ciudad y a la densidad misma del cinturón hortícola. La mayor parte de las huertas $(75 \%)$ contaba con riego; de hecho, con el régimen de lluvias imperante en la región era imposible cultivar árboles frutales, ya no digamos hortalizas. Por esta precisa razón 


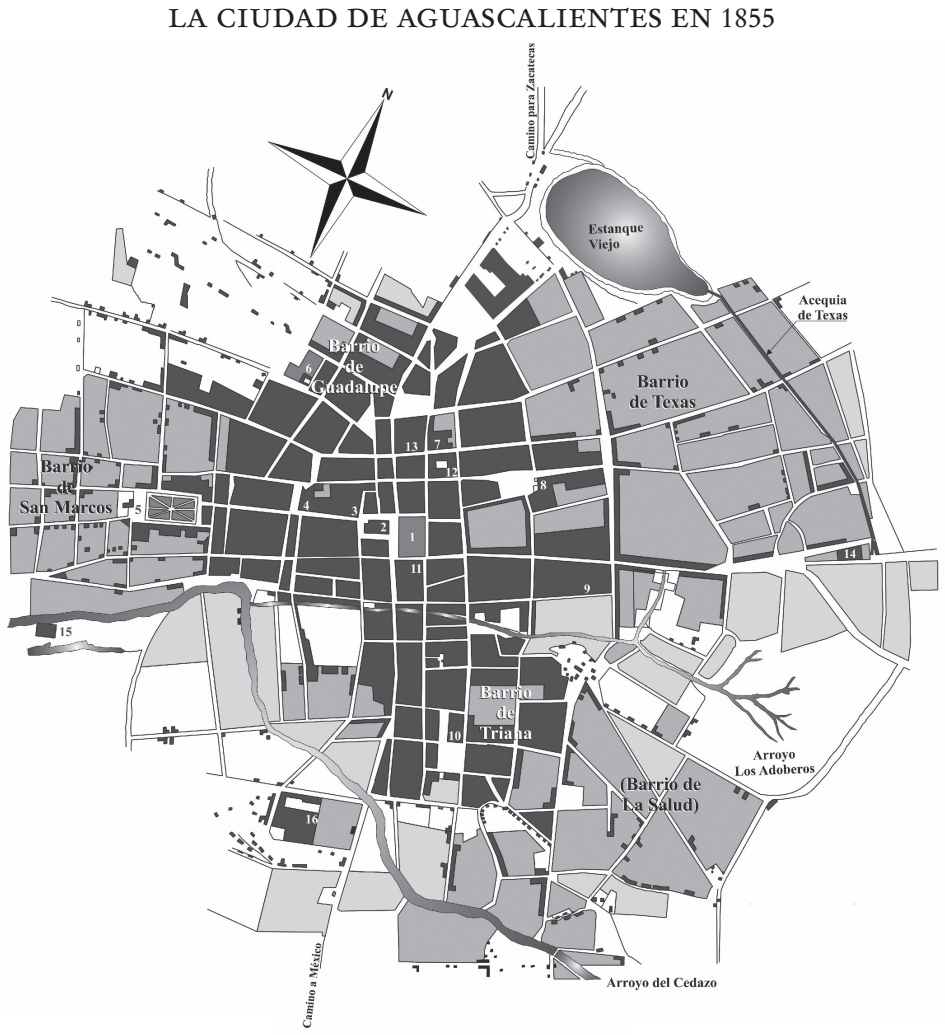

- Cuerpos de agua

Huertas con riego de Ojocaliente

\section{Referencias}

1 Plaza Mayor

2 Parroquia

3 San Ignacio

4 La Merced

5 San Marcos

6 Guadalupe
7 San Diego

8 San Juan de Dios

9 San Juan Nepomuceno

10 El Encino

11 Casa Municipal

12 Parián
Huertas sin riego de Ojocaliente Construcciones

13 Instituto Literario

14 Baños de los Arquitos

15 Panteón de San Marcos 16 El Obraje

Fuente: elaboración propia a partir de Isidoro EPSTEIn, "Plano de las huertas de Aguascalientes”, 1855. Dibujo de Marlene Barba Rodríguez. 
puede inferirse que las huertas dibujadas con color amarillo, para denotar que no recibían agua de Ojocaliente, contaban con alguna noria, pozo o sistema propio de abasto, pues de otra manera sencillamente no podían subsistir como tales.

En este marco de referencia se entiende mucho mejor lo que escribió Eduardo J. Correa sobre las huertas de la ciudad en su libro Un viaje a Termápolis, aunque no conoció el plano de Epstein, o por lo menos no lo alude. Conviene tener en cuenta que Correa compuso su trabajo a partir de "un pequeño libro de apuntes", "unas memorias incompletas y de sello personalísimo" que dejó su padre, el abogado Salvador Correa. No fue concebido como novela, e incluso su autor confiesa que para redactarlo se dio "una tregua" en sus "labores de novelista". Se trata más bien, como indica con claridad poética el subtítulo, de "óleos antiguos", "costumbres que por largos lustros remarcaron la fisonomía de Termápolis", "rasgos de ingenio y anécdotas pintorescas", páginas en las que se busca "prescindir de la fantasía", aunque sin conseguirlo "plenamente". Al mismo tiempo, es un relato que no omite "ciertos apuntamientos históricos" y que trata de ajustarse "a la realidad de los hechos". ${ }^{18} \mathrm{La}$ acción inicia el " 1 o de mayo de $187 . .$. ”, justamente con el viaje que desde Guadalajara emprende el protagonista con el propósito de establecerse en "Termápolis" como juez. Los 47 capítulos del libro son otras tantas estampas de la vida de la ciudad, "óleos" referidos a lugares específicos (el jardín de San Marcos, la Plaza de Armas o el Parián), fiestas (12 de diciembre, navidad, cuaresma), costumbres (los paseos a San Ignacio, "los cotarros femeninos"), personajes (el dentista

${ }^{18}$ Correa, Un viaje a Termápolis, pp. 7-9. 
francés Luis Magnin, el fraile franciscano Boneta, horticultor por cierto) entre otros.

Las huertas, "algo típico en Termápolis”, ocupan un capítulo especial. Debe repararse de entrada en el hecho mismo, porque a los habitantes del lugar, familiarizados con ellas, no parecían llamarles tanto la atención, por lo menos hasta el punto de describirlas o enumerarlas; en cierta forma, su presencia era tan obvia y abrumadora que se habían vuelto invisibles. Fue precisamente un forastero quien dibujó el "Plano de las huertas" y otro recién llegado quien advirtió su masiva presencia, el tremendo peso específico que tenían en el paisaje local, el hecho de que estrechaban la ciudad "con cinturón de esmeralda" y le rodeaban "el talle como una caricia”. La evocación tiene un claro carácter poético, pero si la cotejamos con el plano de Epstein advertimos su exactitud: "no hay barrio que se recorra donde no se asome, trepada a las bardas de adobe, la alegría de las arboledas, que a veces echan sobre las aceras el lujo de sus draperías”. Y asombrado, el recién llegado insiste: "se recorre en circuito la ciudad y no se encuentra lugar donde no se vea alguna huerta, escondiendo en su interior paisajes de jardín”. ${ }^{19}$

Según el relato, el abogado "se propone recorrerlas por el exterior" y "contarlas", para lo cual, acompañado de su hostelera, pasea en un landó destartalado por toda la ciudad. El itinerario lo fija la anfitriona y comienza "por la salida para el río", en el antiguo pueblo de San Marcos, para terminar en el Obraje, la antigua y para entonces abandonada fábrica de textiles, una extensión por el poniente del barrio de Triana. Había que "recorrer toda la población por sus barrios"

${ }^{19}$ Correa, Un viaje a Termápolis, pp. 127-135. 
y convenía apurarse pues estaban en mitad del verano y "el calor sofocante presagia lluvia”. Los barrios aludidos no son esos grandes sectores que con fines de análisis se mencionan habitualmente (Triana, Texas, San Marcos y Guadalupe), sino subdivisiones más pequeñas y cercanas a sus habitantes, cuyos nombres aluden a alguna singularidad del lugar (los Pirules, Cholula, la garita de Zacatecas, el Estanque, el Arroyo), una calle específica (Apostolado, el Olvido, Ojocaliente) o la ocupación de sus vecinos (las Alfarerías, los Caleros, las Tenerías). En total se mencionan 19 "barrios” y la enumeración no es exhaustiva, como lo indican los puntos suspensivos que terminan el listado. Eso sí, “en casi todos” los paseantes vieron viejas “tapias grises, sin enjalbe las más, carcomidas en sus bases”, pero cubiertas por la yedra, el musgo o las flores silvestres, lo que daba al conjunto un agradable aspecto. Las huertas tenían "minúsculas puertas desvencijadas" que disimulaban el recinto interior, lleno de "fragancias, draperías maravillosas, cánticos, silencio, paz”; en resumen, eran verdaderos "remansos de ensueño". ${ }^{20}$ En forma muy clara Correa subraya la función lúdica de las huertas, el hecho de que, al igual que en la España musulmana, constituían el “ornato de la ciudad”, esos jardines a los que sus dueños se retiraban en busca de reposo y distracción. ${ }^{21}$

Y lo que encuentra adentro de las huertas, sobre todo las más extensas y mejor cuidadas, como la de don Lázaro Medina, ${ }^{22}$ es una gran “diversidad de árboles frutales”. Peras

20 Correa, Un viaje a Termápolis, p. 129.

21 Florentino Castro Guisasola, El esplendor de Almería en el siglo XI, citado por Segura del Pino, Agua, tierra y sociedad en el río de Almería, p. 47.

22 La referencia a este propietario es exacta, pues en 1884 , con 30 horas 
de muchas especies y denominaciones ("Chiquitas de San Juan, Cristalinas, de Leche, Bergamotas y quién sabe cuántas más"), chabacanos, higueras "llenas de higos de cáscara negra o blanca", "granados con sus banderolas rojas", "moras almibaradas que parecen formadas con un engarce de chaquiras", naranjos, perones, tejocotes, membrillos, ciruelos, duraznos, limoneros [...] Y en muchas, un tablón de viña "que con sus follajes tiende luengos palios de sombra”. Curiosamente, Correa no alude a las verduras, pero ello no se debe a que encontrara menos lirismo en los jitomates y las cebollas que en las "peras de leche" y las "moras almibaradas", sino al tiempo que transcurría entre un riego y otro (dos meses o más), lo que impedía su cultivo. Como dijo otro autor, la hortaliza requería "irrigaciones frecuentes y metodizadas", que era incapaz de proporcionar el manantial de Ojocaliente a las huertas de la ciudad..$^{23}$ De hecho, en 1892 el cabildo decidió dar riego sólo "a las huertas de árboles frutales y viña, y no a las de hortaliza”. ${ }^{24}$

Luego de recorrer en su landó todos los barrios de la ciudad y de comer fruta en diversas huertas, Correa concluyó que "el hechizo no está en la abundancia", "la fecundidad de la tierra" o "la majestad" de algunos árboles, "sino en el conjunto, en el espectáculo escénico de la huerta toda”, que halagaba la vista y recreaba el olfato, cuyas soledades arropaban al visitante "con edredones de ensueño". ${ }^{25} \mathrm{Al}$ inicio de

de riego en cada tanda, era uno de los que más agua recibía en el barrio de Triana. AGMA, $H$, c.129, exp. 3 y c. 139, exp. 18.

${ }^{23}$ Pérez Arce, "Ideas generales sobre un proyecto económico", pp. 206211.

24 “Aviso a los dueños de las huertas”, El Republicano (12 jun. 1892).

25 Correa, Un viaje a Termápolis, pp. 132-133. 
su paseo, el juez se había propuesto contar las huertas, pero abrumado por la cantidad desiste y reconoce que es sencillamente "imposible conservar la cuenta”.

“EL ESPECTÁ́CULO ESCÉNICO DE LA HUERTA TODA”

La villa de Aguascalientes se fundó en 1575, pero no fue sino hasta la primera década del siglo XviI cuando se desprendió de Lagos, erigiéndose en capital de alcaldía mayor y cabecera de parroquia. Gracias a la abundancia de agua proveída por el manantial de Ojocaliente se formaron numerosas huertas. En 1644 el visitador Cristóbal de Torres ajustó una composición con 62 vecinos, dueños de "huertas, chilares y casas de vivienda” en la villa y en el barrio de Triana, al otro lado del arroyo. También los indios del pueblo de San Marcos, al poniente de la villa y dentro de sus ejidos, regaban sus pequeños huertos con agua del manantial. En el curso de la segunda mitad del siglo XVII Triana experimentó un vigoroso desarrollo y sus huertas se multiplicaron, al mismo tiempo que la "villa" propiamente dicha se consolidaba como un centro urbano y administrativo. Hubo muchos problemas entre los horticultores de Triana, los indios de San Marcos, los padres del convento de La Merced y las autoridades de la villa por el acceso al agua de Ojocaliente, que se resolvieron imponiéndoles a los de Triana la obligación de aportar dinero al fondo de propios de la villa, definiendo los días en los que los indios podían regar sus tierras e incluso, en casos extremos, ordenándose la destrucción de algunos plantíos. En los documentos se lee que las partes se culpaban unas a otras por la "escasez" del agua, pero en el fondo era un problema de gestión, originado por el crecimiento de la villa, la 
multiplicación de huertas, los abusos de "los poderosos", las astucias de "los pobres chileros del barrio de Triana", la tenacidad de los indios de San Marcos y el hecho de que un creciente número de vecinos usaba agua "sin tener títulos de merced". Como explicó en 1714 el abogado del convento de La Merced, el lugar no dejaba de crecer y todos los vecinos parecían aplicados "a formar opulentos chilares y duplicadas huertas, y muchas viñas y arboledas". ${ }^{26}$

En 1789 la villa de Aguascalientes era la capital de una de las subdelegaciones de la intendencia de Guadalajara, aunque Zacatecas la codiciaba, sobre todo por su crucial ubicación en los caminos de Tierra Adentro; tenía unos 8500 habitantes y sus arrabales abandonados eran un vivo recuerdo de la terrible epidemia de 1785-1786, que había cobrado la vida de unas 1500 personas en el lugar y obligado a huir a otras tantas. ${ }^{27}$ En la villa había 104 huertas y 107396 cepas, según el padrón formado por el procurador Gómez de Hermosillo. Cabe aclarar que en ese tiempo viña y huerta eran dos denominaciones de lo mismo, "un pedazo de terreno plantado de cepas", hortaliza y árboles frutales, y que en la villa sólo había dos o tres "viñas formales", cultivadas con el esmero necesario para producir uva apropiada para la fabricación de vino y aguardiente. En su mayor parte las viñas se hallaban "plantadas en corto número en las huertas y patios de las casas", compartiendo el terreno con almácigas de chile, verduras y árboles frutales, principalmente perales, duraznos y membrillos. Como tendremos ocasión de ver más adelante, esa costumbre nunca fue erradi-

26 Chevalier, La formación de los latifundios en México, pp. 272-277; Gómez Serrano, "Una historia escrita con tinta de agua”, pp. 37-81.

27 Herrera y Leyva, "Descripción de la subdelegación de Aguascalientes”, pp. 19-20; RoJAs, Las instituciones de gobierno y la élite local, p. 121. 
cada. ${ }^{28}$ En 1792 Félix Calleja consignó que había 140 huertas que producían "muchas frutas de Europa”, aunque lamentó que las acequias fueran "simples zanjas sin revestimiento en las que se consume la mayor parte del agua que debería llegar a las huertas, por cuyo motivo no sólo no se aumentan éstas, sino que anualmente se secan algunas, no pudiendo subsistir en este país ningún plantío sin riego". ${ }^{29}$

\section{Cuadro 1}

HUERTAS EN LA VILLA DE AGUASCALIENTES

A FINES DEL SIGLO XVIII

\begin{tabular}{lcccccc}
\hline Barrio & \multicolumn{2}{c}{1789} & \multicolumn{2}{c}{1791} & \multicolumn{2}{c}{1797} \\
\cline { 2 - 7 } & $\begin{array}{c}\text { Canti- } \\
\text { dad }\end{array}$ & $\begin{array}{c}\text { Exten- } \\
\text { sión }\end{array}$ & $\begin{array}{c}\text { Canti- } \\
\text { dad }\end{array}$ & Extensión & $\begin{array}{c}\text { Canti- } \\
\text { dad }\end{array}$ & Extensión \\
\hline Triana & n.d. & n.d. & 28 & 12.2481 & 39 & 16.1113 \\
Texas & n.d. & n.d. & 68 & 22.4768 & 84 & 26.8668 \\
San Marcos & 12 & n.d. & 26 & 2.3706 & 26 & 2.3706 \\
Villa & n.d. & n.d. & 19 & 4.3022 & 22 & 4.8290 \\
Totales & 104 & $31.7301 *$ & 141 & 41.3977 & 171 & 52.1717 \\
\hline
\end{tabular}

Fuente: "Razón de las huertas que tienen viña en esta villa con expresión de las cepa de que se compone cada una" (19 de diciembre de 1789) y "Reconocimiento de huertas, sus terrenos, número de viñas que cada una tiene y los dueños a quien pertenecen" (27 de junio de 1797), AGN, IC, vol. 17, 112f.-113v. y 148f.-153v.

En los documentos la extensión está indicada en solares, convertidos a hectáreas a razón de $1756 \mathrm{~m}^{2}$ por solar.

* El padrón de 1789 no indica la extensión de las huertas, pero está calculada a partir de la extensión promedio que tenían en 1797.

${ }^{28}$ AGN, IC, vol. 17, 112f.-113v. "Razón de las huertas que tienen viña en esta villa con expresión de las cepas de que se compone cada una”, 19 de diciembre de 1789.

${ }^{29}$ AGN, $P$, vol. 5, 1v., "Descripción de la subdelegación de Aguascalientes", 15 de junio de 1792 . 
En 1797 el subdelegado Carrillo y Vértiz hizo un nuevo "reconocimiento de huertas", que detallaba las que fueron “plantadas después de 1791". Según este recuento había 171 huertas y 279923 cepas. El barrio de Texas, que se estaba formando en esos años, concentraba la mitad de las huertas y poco más de las cepas censadas. La mayor parte de las huertas (106) medían menos de un solar y había muchas (29) que ocupaban apenas un cuarto de solar $\left(439 \mathrm{~m}^{2}\right)$, el equivalente del jardín en una residencia moderna. A su lado había unas pocas que se distinguían por su tamaño y su potencia productiva. La más extensa pertenecía al regidor José María Cardona, medía 19 solares (33.364 ha) y albergaba 19059 cepas; la del recaudador de alcabalas, Jacinto López Pimentel medía 131⁄2 solares y tenía 13780 cepas. Según Carrillo, el propósito de éste era "establecer un giro de negociación en fábricas de vinos y aguardientes", lo que en todo caso frustró la orden real del 19 de marzo de 1796, que autorizó la fabricación y el consumo de chinguirito en toda la Nueva España, pues en Aguascalientes los viñedos funcionaban como tapadera de fábricas clandestinas de aguardientes contrahechos. ${ }^{30}$ $\mathrm{Al}$ margen de esto, es notable la rapidez con que se expandía la horticultura a fines del siglo xviII.

En un informe redactado en 1813 se dice que la villa tenía 11580 habitantes, aunque se creía "que a los empadronadores se les haya ocultado alguna gente", lo que elevaría el total “a 13500 y más almas". De las huertas se dice tan sólo que "producen frutas de buena calidad como son pera, higo, durazno,

30 Lozano Armendares, El chinguirito vindicado, pp. 25-26, 121, 135; Rojas, "El cultivo de la vid", pp. 35-57; Gómez Serrano, "Las huertas y la vid, el vino y el chinguirito", pp. 123-187. 
uva, granada, membrillo y chabacano, como también verdura de casi todas clases", añadiéndose que no era desdeñable su importancia económica, "por la extracción que se hace para su venta a varios lugares de los alrededores". ${ }^{31}$ Por su parte, los autores del Primer Cuadro Estadístico del Departamento de Aguascalientes, hecho en 1837, se limitaron a referir la "multitud" de huertas que había en la ciudad, en las cuales se disponían agraciados y sencillos jardines que procuraban "desahogo y recreación” a sus propietarios. El lugar, al que en 1824 un decreto del congreso de Zacatecas le había concedido el título de ciudad, tenía según ellos 19600 habitantes, aunque parece que la cifra se exageró, pues se quería subrayar su importancia y justificar su carácter de capital departamental. ${ }^{32}$ En un informe de 1844 se decía que en las huertas de la ciudad "se dan en abundancia y vegetan bien todas las plantas de clima frío": 14 variedades de pera, 5 de manzana, 2 de perón, 2 de ciruela, duraznos, chabacanos, capulines, moras, higos, granados, naranjos, toronjas, limas, limones, uvas y zapote blanco. Se añadía que estaban tan extendidas las huertas y era tan abundante la producción de fruta que el provecho que obtenían los cultivadores era mediocre. ${ }^{33}$

31 AHMG, Censos 1813-1814, leg. 28-2. "Censo de la villa de Aguascalientes y su jurisdicción”, 1813.

32 Ávila, Romo de Vivar, Calera y Semería, "Noticias estadísticas del Departamento de Aguascalientes”, p. 181; Amador, Bosquejo histórico de Zacatecas, t. II, pp. 294-295. En el contexto de la crisis de la primera república federal Aguascalientes fue erigido en territorio de la federación (1835) y luego en departamento de la república central (1836).

33 BSHGEA, t. I, núms. 7, 8 y 9, 1935, pp. 11-14. "La industria y la agricultura en 1844. Copias de los documentos que se citan en la Memoria presentada al Supremo Gobierno por la Dirección General de la Agricultura e Industria Nacional relativa al año de 1844.” 
En su "Cuadro Sinóptico de Aguascalientes" Epstein consignó que la ciudad tenía 22543 habitantes y 398 huertas; no sabemos de dónde sacó el dato de población pero con seguridad el de huertas lo obtuvo de los padrones municipales de regadío y por tanto se refiere sólo a las que pagaban derechos de agua. El dato corresponde a la misma época en que dibujó su plano de las huertas (1855), aunque el Cuadro se publicó en 1861 y tal vez por su rareza fue una de las principales atracciones de la Exposición de Artes e Industria de ese año. ${ }^{34}$

Si tenemos en cuenta que en 1797 Carrillo y Vértiz contó 171 huertas con riego en toda la villa, podemos concluir que a lo largo de la primera mitad del siglo xIx el perímetro hortelano de la ciudad siguió creciendo y consolidándose, lo que pone en su lugar las alusiones a la "decadencia" del ramo que se leen en los documentos de la época, que en realidad remiten a las dificultades anejas a la gestión del sistema de riego, los errores y trampas de quienes lo administraban y sobre todo las ruidosas y siempre interesadas quejas de los horticultores.

Una impresión parecida tenemos al considerar no el número de huertas sino su extensión. A fines del siglo xviII, según las cuentas del subdelegado, las huertas de toda la villa ocupaban una superficie de 285 solares, equivalentes a 50.046 ha. A partir del plano de Epstein se puede calcular que ocupaban poco más de 200 ha, cuatro veces más. Todo ello quiere decir que en el curso de la primera mitad del siglo xIX el huerto urbano creció en forma notable, tanto en términos del número de plantíos como de la superficie que ocupaban.

En enero de 1883, en su carácter de "juez para la dirección de las aguas", Luciano Medina formó un "padrón general del regadío de las huertas” de la ciudad, agrupándolas según la

34 Epstein, Cuadro Sinóptico de Aguascalientes; El Porvenir (5 mayo 1861). 
acequia que las regaba: la del sur, correspondiente de manera aproximada al antiguo barrio de Triana, y la del norte, que abarcaba los barrios de Texas, Guadalupe, San Marcos y el casco histórico. Esta gran división entre sur y norte estaba definida por el arroyo de Los Adoberos, que partía en dos la ciudad. La acequia de Triana regaba 250 huertas y la de Texas 209, lo que daba un total de 459 huertas con derecho a riego. La manzana de la discordia estaba constituida por las 35 huertas que había en las calles del Olivo (hoy Zaragoza), al norte del arroyo, que eran regadas por la acequia sur, hecho en el que los vecinos de Triana veían una injusticia. Para entonces, la ciudad tendría unos 30000 habitantes. ${ }^{35}$

De los padrones correspondientes al siglo xIX que conocemos éste es el mejor. No incluye las huertas que no contaban con riego, lo cual elevaría el total hasta 600 o poco más. Fue formado casi 30 años después de que Epstein dibujara su plano, pero sus datos pueden "leerse" sin dificultades en ese mapa. Tampoco hay diferencias abismales entre el total de huertas que indicó Epstein en su Cuadro Sinóptico de 1861 (398) y el que proporciona el padrón de 1883 (459), de donde puede inferirse que el huerto urbano siguió creciendo en el periodo 1850-1880, alcanzando tal vez su punto de mayor expansión justo en la época a la que corresponde la recreación de Correa. La misma época a la que se refería Jesús F. López, periodista y horticultor, cuando decía que gracias a sus numerosas y bien cuidadas huertas la ciudad de Aguascalientes había sido conocida como el "país de las flores y los

35 En 1882, 35000 según la estimación no muy confiable de Charles Zeremba, pero sólo 30872 en 1895, según Antonio Peñafiel. Estadísticas, t. I, cuadro 1.51: "Población total de la ciudad de Aguascalientes, Ags. Años seleccionados de 1794 a 2005”. 
frutos". ${ }^{36}$ Parodiándolo, Enrique Fernández Ledesma evocaba "la ciudad de las flores, de los frutos y de las aguas". ${ }^{37}$

\section{Cuadro 2}

HUERTAS CON RIEGO DE LA CIUDAD DE AGUASCALIENTES, 1883

\begin{tabular}{cc}
\hline Sector & Número \\
de huertas
\end{tabular}

1. Padrón General del Regadío de Texas [Acequia Norte]

Manzanas de San Juan de Dios $\quad 29$

Manzanas de La Tenería 16

Manzanas de Francisco S. Rangel 36

Manzanas de Los Castillo $\quad 14$

Manzanas del Tanque $\quad 2$

Regadío de Guadalupe $\quad 11$

Regadío del Pueblo [de San Marcos]

Manzanas de La Palma $\quad 14$

Manzanas de la plaza de toros $\quad 15$

Manzanas del templo de San Marcos $\quad 20$

Manzana de La Primavera 38

Manzana del Plan 4

Manzana de La Merced $\quad 10$

Subtotal Regadío de Texas 209

2. Padrón General del Regadío de Triana [Acequia Sur]

Manzanas del Olivo $\quad 35$

Manzanas de Los Patos $\quad 13$

Manzanas de Los Caleros 33

Manzanas de Alamitos $\quad 20$

Manzanas de Games $\quad 30$

Manzanas del Palo Verde $\quad 14$

Manzanas del Toro $\quad 64$

Manzanas de La Salud $\quad 41$

Subtotal Regadío de Triana $\quad 250$

Total 459

Fuente: "Padrón general del regadío de las huertas" formado por Luciano Medina, 16 de enero de 1883, AGMA, FH, c. 8, exp. 13.

36 "Horticultura en el estado", El Fandango (8 dic. 1895).

37 Fernández Ledesma, “Aguascalientes, la ciudad de las flores”, pp. 230-233. 
Con muchas precauciones, podemos dar un paso más y aventurar una comparación entre los padrones de fines del siglo Xviıi y el de 1883 . Lo primero que salta a la vista es la consolidación del huerto urbano. Pese al fracaso del cultivo de la vid y al severo golpe que representó para la economía del lugar la orden real de 1796 que legalizó la fabricación de chinguirito, las huertas siguieron creciendo en número y extensión, dándole a la ciudad uno de sus rasgos más característicos, como se puede apreciar en el plano de Epstein (1855) y en la recreación literaria de Correa (c. 1870), cuya observación sobre “el espectáculo escénico de la huerta toda" se muestra bien fundada a la luz de estos datos. Las cifras son contundentes: 141 huertas en 1791, 171 en 1797, 398 en 1861 y 459 en 1883, lo que quiere decir que durante el siglo XIX su número casi se triplicó. En términos de superficie, los progresos fueron aún más notables: 50 ha en 1797 y 200 en 1861.

En seguida, reparemos en los cambios operados dentro de la geografía urbana. Triana, nacido en el temprano siglo XVII como barrio de horticultores, consolidó su protagonismo y recuperó el lugar de primacía que a fines del Xviı le había arrebatado Texas, que se formó gracias a la construcción del Estanque y la acequia que lo alimentaba. En 1797 fueron censadas 39 huertas en Triana y 84 en Texas (la mitad), pero en 1883 la situación era exactamente al revés, pues había 215 huertas en Triana y sólo 103 en Texas (el doble). Aun así, en términos de la extensión de los plantíos, el barrio de Texas se mantenía a la cabeza, con 65.79 ha, 43.5\% del total. En San Marcos las huertas se triplicaron (26 en 1797 y 91 en 1883) y, como puede verse en el plano de Epstein formaban un grueso cinturón alre- 
HUERTAS DE LA CIUDAD DE AGUASCALIENTES CON RIEGO DE OJOCALIENTE, ORGANIZADAS POR BARRIO 1855

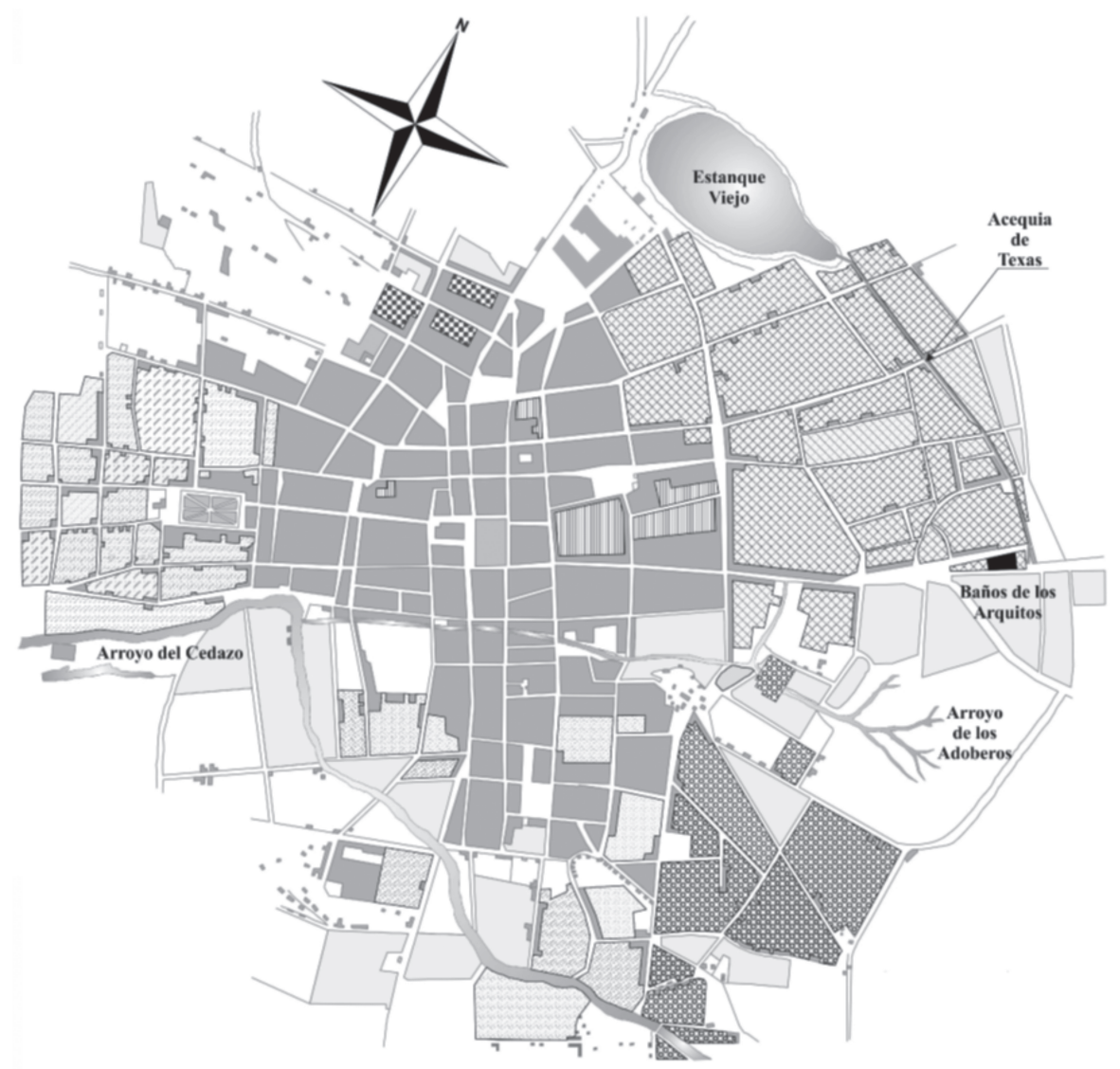

$\square$ San Marcos: 30.2811 ha 阆 Guadalupe: 2.1454 ha Texas: 65.7906 ha
11 Casco antiguo: $5.5452 \mathrm{ha}$ $\square$ Triana: 21.9832 ha La Salud: 25.3101 ha $\square$ Huertas con riego del Ojocaliente: 151.0559 ha $\square$ Huertas sin riego del Ojocaliente: 56.0311 ha Superficie total: 207.0870 ha

Fuente: elaboración propia a partir de Isidoro Epstein, "Plano de las huertas de Aguascalientes”, 1855. Dibujo de Marlene Barba Rodríguez. 
dedor del jardín. El pueblo de indios desapareció como tal entre 1826 y 1834, lo que dio pie a la formación de un barrio característico por su huerto. En el casco antiguo de la ciudad, lo que propiamente había sido la villa durante los siglos XVII y XVIII, las huertas conservaban cierta importancia: había 29 en los alrededores del antiguo hospital de San Juan de Dios (hoy San José) y 10 en la zona del templo y convento de La Merced, 39 en total, según el padrón de 1883. Medida en términos relativos, la importancia de estas huertas disminuyó, pues si en 1791 las huertas "de la villa" eran $14 \%$ del total, en 1883 representaban sólo 8.5\%. Esto es muy visible en el plano de Epstein, en el que con excepción de algunos manchones verdes, el centro de la ciudad está urbanizado casi por completo. Señalemos por último la emergencia de Guadalupe, barrio que empezó a formarse a fines de la época colonial y en el que por entonces se cultivaba algo de maguey; ${ }^{38}$ el padrón de 1883 le asigna 11 huertas, apenas $2.4 \%$ del total. En resumen, tres grandes sectores o barrios (Triana-La Salud, Texas y San Marcos) formaban ese "cinturón de esmeralda" que en la época de Epstein y Correa ceñía casi por completo la ciudad. En este sentido, puede decirse que las observaciones de este último no son sólo literatura, sino también una recreación ajustada a las realidades urbanas.

38 AHEA, E, c. 3, exp. 3. "Relación de dueños de magueyes en los barrios de Triana, Texas y Guadalupe”, 12 de julio de 1803. 


\section{Cuadro 3}

EVOLUCIÓN DEL HUERTO DE LA CIUDAD

DE AGUASCALIENTES, 1791-1883*

\begin{tabular}{lcccccc}
\hline Barrio & \multicolumn{2}{c}{1791} & \multicolumn{2}{c}{1797} & \multicolumn{2}{c}{1883} \\
\cline { 2 - 7 } & $\begin{array}{c}\text { Canti- } \\
\text { dad }\end{array}$ & $\begin{array}{c}\text { Exten- } \\
\text { sión }\end{array}$ & $\begin{array}{c}\text { Canti- } \\
\text { dad }\end{array}$ & $\begin{array}{c}\text { Exten- } \\
\text { sión }\end{array}$ & $\begin{array}{c}\text { Canti- } \\
\text { dad }\end{array}$ & $\begin{array}{c}\text { Exten- } \\
\text { sión }\end{array}$ \\
\hline Triana-La Salud & 28 & 12.2481 & 39 & 16.1113 & 215 & 47.2900 \\
Texas & 68 & 22.4786 & 84 & 26.8668 & 103 & 65.7900 \\
San Marcos & 26 & 2.3706 & 26 & 2.3706 & 91 & 30.2800 \\
Villa & 19 & 4.3022 & 22 & 4.8290 & 39 & 5.5500 \\
Guadalupe & 0 & 0 & 0 & 0 & 11 & 2.1500 \\
Totales & 141 & 41.3995 & 171 & 50.1777 & 459 & 151.0600 \\
\hline
\end{tabular}

Fuente: Para 1791 y 1797: "Reconocimiento de huertas, sus terrenos, número de viñas que cada una tiene y los dueños a quien pertenecen", AGN, IC, vol. 17, 148f.-153v.; para 1883: "Padrón general del regadío de las huertas", AGMA, $F H$, c. 8, exp. 13.

La extensión está indicada en hectáreas; en los casos de 1791 y 1797 está tomada de los documentos, en el de 1883 es una estimación propia a partir del "Plano de las huertas" de Epstein.

"Sólo se incluyen las huertas con riego del manantial de Ojocaliente.

\section{DESCRIPCIÓN DEL SISTEMA DE RIEGO}

El sistema de acequias de la ciudad de Aguascalientes es un buen ejemplo de eso que se ha llamado "pequeño riego", caracterizado por la sencillez de las obras que permiten el control de las aguas. Cuando se habla de irrigación habitualmente se piensa en costosas presas de mampostería y grandiosos acueductos, obras faraónicas que suponen la desviación de grandes corrientes y la creación ex nibilo de distritos de riego, con un impacto en los ecosistemas que prefiere ignorarse; pero a su lado ha habido desde épocas 
remotas, en Babilonia, la Andalucía musulmana y Mesoamérica, obras sencillas pero enormemente útiles que se valen del propio entorno, la inclinación del terreno y la existencia de vasos o depósitos naturales, para domesticar el agua e irrigar un determinado paraje. ${ }^{39}$ En el México decimonónico había muchas de estas obras modestas y baratas, cuyo manejo no exigía "personal especializado", pues "el conocimiento local era suficiente". ${ }^{40}$

El agua que brotaba del manantial de Ojocaliente, al pie de un pequeño promontorio, $2800 \mathrm{~m}$ al oriente de la plaza, corría de este a oeste a lo largo del "camino del Ojocaliente” en dirección a Los Arquitos, la plaza y más allá. Ello era posible gracias a la pendiente natural del terreno: $1894 \mathrm{msnm}$ en el manantial, $1884 \mathrm{msnm}$ en los baños, $1874 \mathrm{msnm}$ en la plaza, 1865 msnm en San Marcos y 1862 msnm en la confluencia de los arroyos de Los Adoberos y del Cedazo, el punto más bajo de todo el sistema. La diferencia de alturas entre el manantial y San Marcos es de $29 \mathrm{~m}$, lo que forma una pendiente muy suave, de menos de un grado, suficiente para permitir que el agua llegara por gravedad a todos los barrios de la ciudad y regara sus huertas sin necesidad de un ingenio mecánico adicional.

Originalmente el manantial formaba un "arroyuelo perpetuo" que proveía "agua muy dulce y sana" al vecindario. ${ }^{41}$ En algún punto, la corriente drenaba en el "arroyo de la villa", llamado después de Los Adoberos, el cual a su vez era tri-

\footnotetext{
39 Véanse los trabajos reunidos por Palerm Viqueira y Martínez SaLDAÑA en los tres volúmenes de su Antología sobre pequeño riego.

40 Aвoites, El agua de la nación, p. 30.

41 Mota y Escobar, Descripción geográfica, p. 58.
} 
butario del río San Pedro, el más importante de la jurisdicción. El crecimiento de la villa y la multiplicación de huertas hicieron necesaria la construcción de una acequia en forma, que alteró el curso del arroyo. Con seguridad, se trataba de una obra de ingeniería muy modesta pero que satisfacía con razonable suficiencia los requerimientos del lugar. A veces se habla del acueducto del Ojocaliente, lo que sugiere una obra de cierta entidad, comparable a los construidos en otras ciudades, como Querétaro o Zacatecas, ${ }^{42}$ pero en realidad lo que había era una zanja o acequia sin revestimiento que seguía el curso serpenteante del arroyo. Ello era así porque nunca hubo dinero para construir un acueducto en forma, pero sobre todo porque no se necesitaba, pues la pendiente natural del terreno y las acequias a cielo abierto hacían todo el trabajo. Este trazo no se rectificó sino hasta 1899, en el contexto de la mejora integral del sistema de abasto de agua promovida por el gobernador Rafael Arellano. ${ }^{43}$ Antes de la construcción de esta acequia, buena parte del agua se perdía en el trayecto, formando grandes charcos y "placeres" que eran "el lavadero público y la alberca de la clase pobre de esta población". ${ }^{44}$ A todo lo largo de la época colonial y el siglo XIX nunca se supo a ciencia cierta qué cantidad de agua

42 El espectacular acueducto de Querétaro se concluyó en 1738 y tuvo un costo de 100000 pesos. Loyola Vera, Sistemas hidráulicos en Santiago de Querétaro, pp. 117-155; el de Zacatecas, menos imponente, se construyó en el siglo xviII, bajo el patrocinio la diputación de minería. HuRTAdo Hernández, "La ciudad sedienta”, p. 78.

${ }^{43}$ Martínez Delgado, Cambio y proyecto urbano, pp. 153-156; Delgado Aguilar, "Obra pública, cambio urbano y protesta social”, pp. 85-97.

${ }^{44}$ Díaz de León, “Apuntes para el estudio de la higiene”, pp. 188, 200-201. 
brotaba del manantial, cuánta era la que llegaba a la ciudad y cuál el caudal del que se disponía para regar la huerta; sin considerar las dificultades técnicas que ello hubiera entrañado, no se hizo esa medición exacta porque era innecesaria, toda vez que el agua que llegaba a los diversos barrios de la ciudad abastecía las huertas con razonable suficiencia, de acuerdo con la práctica secular. En octubre de 1856, cuando la Ley de Desamortización de Bienes de las corporaciones obligó al cabildo a vender los baños de Los Arquitos, la única previsión que se tomó fue la de reservar una naranja de agua (388 l por hora, $93.3 \mathrm{~m}^{3}$ diarios) "para las fuentes públicas”; el resto, después de pasar por los baños y sin que su volumen fuera calculado, siguió destinándose al riego de las huertas, como siempre..$^{45}$

No fue sino hasta abril de 1896 cuando Tomás Medina Ugarte determinó con procedimientos técnicos modernos y creíbles que el manantial descargaba 1037 litros de agua por minuto, "equivalentes a dieciséis naranjas, si nos referimos a las medidas antiguas". Sin embargo, el acueducto, que tenía una extensión de 1300 m, depositaba sólo 7341 por minuto (algo más de 11 naranjas) en la caja repartidora de los baños de Los Arquitos, lo cual quiere decir que debido al pésimo estado de la acequia, en el trayecto se perdía casi la tercera parte del líquido. ${ }^{46} \mathrm{~A}$ partir de este informe, el gobierno del estado ideó la construcción de un nuevo acueducto, que

${ }^{45}$ AHEA, $P N$, c. 66, exp. 4, ff. 238v.-245v. Escritura otorgada ante el escribano Candelario Medina el 6 de octubre de 1856.

${ }^{46}$ AGMA, $H$, c. 225, exp. 24. En junio de 1898 Medina Ugarte hizo nuevas mediciones y determinó que el agua que se perdía en el trayecto era en realidad equivalente a dos terceras partes de la que descargaba el manantial AGMA, $H$, c. 250, exp. 8. 
ESQUEMA DEL SISTEMA DE RIEGO DE LAS HUERTAS

DE LA CIUDAD DE AGUASCALIENTES, C. 1840

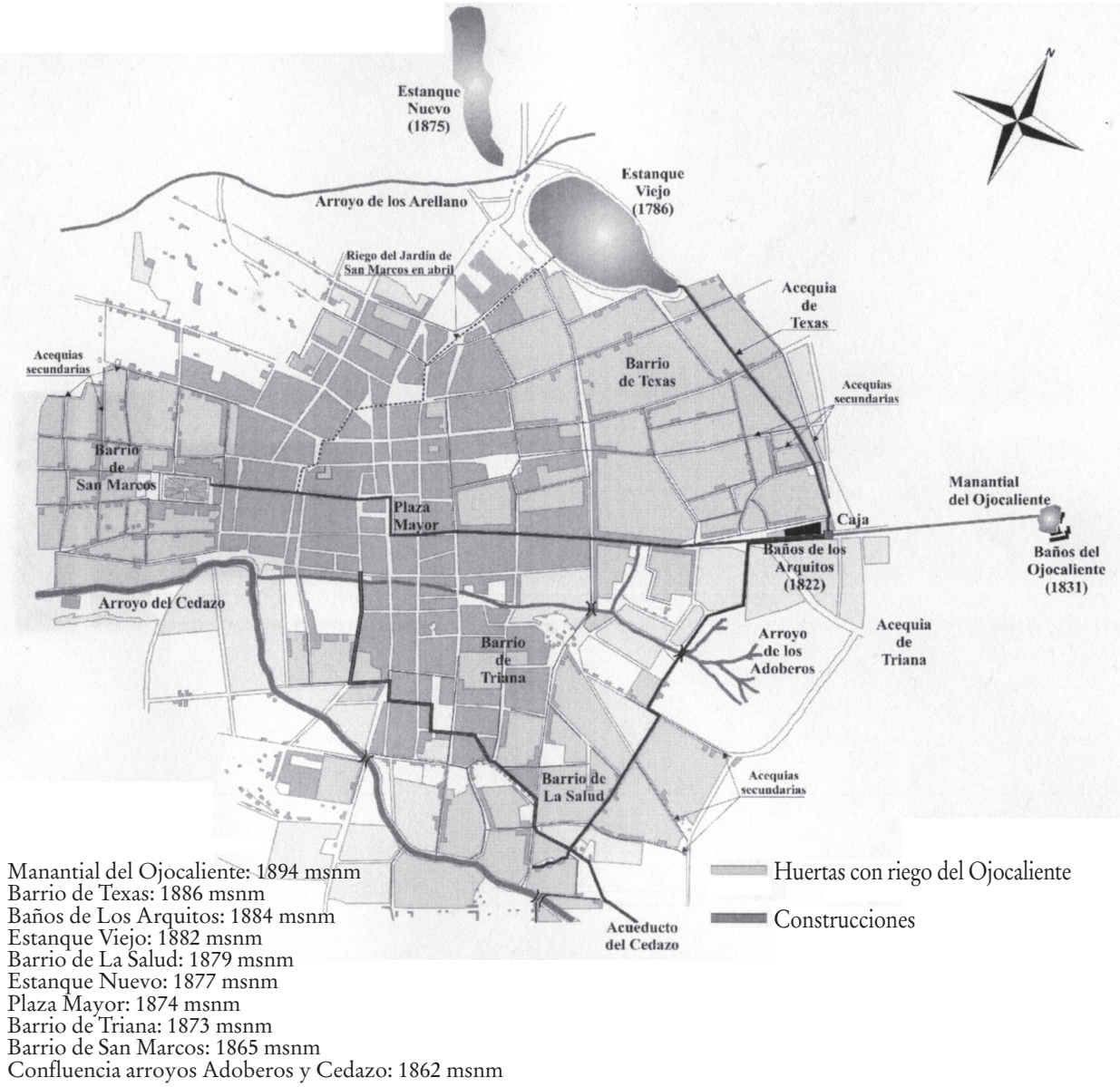

Fuente: Altitudes: datos obtenidos del Google Earth.

Fuente: elaboración propia a partir de Isidoro Epstein, "Plano de las huertas de Aguascalientes", 1855. Tomás Medina Ugarte, "Plano de la ciudad de Aguascalientes" (1900) y documentación procedente del AGMA, FH. Dibujo de Marlene Barba Rodríguez. 
abatiera sustancialmente las mermas, e inició negociaciones con los dueños de los baños, tendientes a modificar la fórmula con que se repartía el agua. ${ }^{47}$

Durante todo el siglo xviI y la mayor parte del xviII hubo una sola acequia, que corría a lo largo del paseo de Ojocaliente, a partir de la cual se formaban acequias secundarias, que "sangraban" los propietarios para regar sus huertas. Cuando se construyó la acequia en Texas (1786), se habilitó una caja que repartía el agua entre las dos acequias principales: la de Triana por el sur y la de Texas por el norte. Justo en el lugar donde estaba la caja, en 1822 se construyeron, a instancias del cabildo constitucional, los baños de Los Arquitos, cuyo desagüe formó la acequia de Texas. Hasta donde entendemos, el agua que corría por la acequia de Triana no pasaba por los baños y por lo tanto sería más limpia, aunque eso a nadie le importaba porque era agua para riego, no para consumo humano. Aparte de las acequias de Texas y Triana existía la cañería que conducía el agua que abastecía las fuentes públicas de la ciudad, la naranja que se reservó el cabildo en 1856. Esta cañería corría paralela al acueducto, a todo lo largo del paseo de Ojocaliente. La apertura de la acequia de Texas dio origen al barrio de ese nombre, característico por sus huertas, un auténtico barrio huerto durante todo el siglo xix. Los sobrantes de esta acequia se reunían en el tanque o estanque de la Alameda, que se construyó al mismo tiempo que la acequia, en $1786 .{ }^{48}$ Es claro que, al igual que en Apatzingán y Uruapan, cuyas huertas también eran regadas por manantiales, la traza urbana de Aguascalientes fue

47 Martínez Delgado, Cambio y proyecto urbano, p. 153.

48 Salas López, Para la historia de Aguascalientes, pp. 241-242. 
poderosamente marcada por la red de acequias que llevaban el agua a los principales barrios de la ciudad. ${ }^{49}$

En 1797, el rico comerciante peninsular Miguel Antonio Gutiérrez, consciente de "la mucha escasez de agua que en los tiempos más precisos del riego de las huertas padecen los hortelanos", dejó en su testamento un legado "de 3 a 4000 pesos" con el que debía construirse "un estanque de magnitud bastante para recoger en él el agua que no se aprovecha en los tiempos que no son de cultivo". ${ }^{50}$ Ello quiere decir que el tanque que había era muy pequeño y no mejoraba la capacidad de riego existente y que durante la época de lluvias el agua del manantial se dejaba correr sin utilidad por las acequias hasta el arroyo del Cedazo, que drenaba en el río San Pedro. No obstante, por razones que ignoramos, esta obra no fue ejecutada y el legado se perdió o fue malversado.

El estanque de la Alameda fue ampliado en la época del jefe político José María Guzmán (1825-1829), quien además plantó árboles en sus alrededores y contribuyó a hacerlo un lugar de paseo. ${ }^{51}$ Se construyó una cortina de calicanto "de cuatro y media varas de elevación [...] reforzada en toda su extensión por un bordo de tierra de espesor de diez a doce varas". ${ }^{52}$ El lugar era "hermoso" y proporcionaba "variadas y halagüeñas vistas", pero la capacidad de almacenamiento del estanque siguió siendo limitada, por lo que auxiliaba sólo

\footnotetext{
49 Sánchez Rodríguez y Boenm Schoendube, Cartografía hidráulica de Michoacán, pp. 162-163.

${ }^{50}$ AHEA, $P N$, c. 34, exp. 3, e. 5, ff. 7f.-15v.

51 González, Historia del estado de Aguascalientes, p. 101.

52 "Primer cuadro estadístico", pp. 179-180. En su "Plano de las huertas de Aguascalientes" (1855), Epstein lo indica también con el nombre de "estanque" y lo dibuja con forma de pera, según esta descripción.
} 
en forma precaria y eventual al sistema de riego de las huertas. Mucho después (1927) se calculó que almacenaba un máximo de $104145 \mathrm{~m}^{3}$ de agua. ${ }^{53}$ Durante la época de lluvias, cuando las huertas no requerían riego, el agua del manantial se encauzaba por medio de la acequia de Texas hasta el estanque, lo que permitía tenerlo lleno. Normalmente se vaciaba en abril, para regar el jardín de San Marcos y mejorar el aspecto que ofrecía durante las fiestas. Esas semanas se aprovechaban para limpiar las acequias y desazolvar el estanque.

Con la idea de elevar la capacidad de almacenamiento de agua y mejorar la oferta de riego, el gobernador Ignacio T. Chávez decidió en 1873 construir un “nuevo” estanque, unos cientos de metros al norte del viejo, en los límites de la ciudad, que captaría las aguas del arroyo de los Arellano. La obra fue ejecutada y costeada por el gobierno del estado, aunque se colectó dinero entre los horticultores. Los trabajos fueron hechos de manera forzada por los presos de la cárcel municipal. La construcción comenzó a mediados de febrero de 1874, bajo los mejores auspicios, pues en la ciudad había muchas huertas y se decía que el cultivo de la vid estaba muy extendido, lo que hacía de esa mejora "un bien inestimable". Los entendidos calculaban que el nuevo estanque triplicaría la capacidad de almacenamiento del antiguo. ${ }^{54}$ El optimismo seguía predominando el domingo 22 de agosto de 1874, cuando la obra se entregó y con ese motivo hubo una fiesta popular que reunió a "3000 o 4000 personas”, que "coronaban el bordo del estanque y poblaban la llanura inmediata”.

53 Delgado Aguilar, "Obra pública, cambio urbano y protesta social”, p. 191.

54 “El nuevo estanque”, El Republicano (19 mar. 1874). 
Miguel Guinchard, un político local que apadrinó la obra, dio "una gratificación a cada uno de los desgraciados presos" que trabajaron en ella. ${ }^{55}$ Según Topete, este segundo esta que se construyó con el propósito de satisfacer las cuotas de riego comprometidas con los hortelanos y regar los nuevos jardines públicos. ${ }^{56}$ En realidad se trataba de un sencillo bordo de tierra de dos metros de altura que retenía las aguas del arroyo de los Arellano; su capacidad se estimó en $70000 \mathrm{~m}^{3}$ de agua, ni siquiera tres cuartas partes del antiguo. ${ }^{57}$

Pronto se constató que el nuevo estanque no captaba tanta agua como se esperaba ni mejoraba sustancialmente la capacidad del sistema de riego. Aunque aplaudía la iniciativa, Agustín R. González dijo que "la obra no fue perfeccionada y no se obtuvieron todos los resultados que se esperaban". ${ }^{58}$ En 1889 Salvador Pérez Arce calculó que con el método de inundación que se usaba los estanques eran capaces de regar "por una sola vez menos de la mitad de los terrenos que forman en conjunto los jardines y huertas que al presente disfrutan de este beneficio"; si se exceptuaba esta "corta utilidad", podía decirse que "los estanques no sirven de nada". ${ }^{59}$ Esto último constituye una exageración, pero es un hecho que las huertas no se regaban con agua de los estanques, como

55 “Apertura del nuevo estanque”, El Republicano (3 sep. 1875).

56 Topete del Valle, Efemérides aguascalentenses (22 ago. 1983).

57 Delgado Aguilar, "Obra pública, cambio urbano y protesta social”, p. 191, nota 455 .

${ }^{58}$ González, Historia del estado de Aguascalientes, p. 272.

59 Pérez Arce, "Ideas generales sobre un proyecto económico", pp. 207211. En realidad Pérez Arce sobrestimó la capacidad de los estanques, pues como acabamos de ver, entre los dos podían almacenar un máximo de $174145 \mathrm{~m}^{3}$ de agua, $70 \%$ de lo que él creía. 
afirman González, Espinoza y otros autores, ${ }^{60}$ sino directamente con la que provenía del manantial y corría por las dos acequias principales de Triana y Texas, dividida mediante multitud de canales o acequias secundarias. También creemos que está fuera de dudas que nunca se construyó el gran estanque que planeó Miguel Antonio Gutiérrez a fines del siglo XVIII.

Según parece existía una antigua costumbre según la cual primero se daba agua a las huertas más alejadas del manantial, las situadas en el extremo poniente de la ciudad, en los terrenos más bajos, y luego se iban recorriendo los riegos hacia arriba, en sentido oriente. Este criterio se fijó en el artículo 2 del reglamento municipal de regadíos de 1872, aunque al parecer había muchas confusiones y abusos, como lo puso de manifiesto una comisión que en 1883 estudió las quejas de algunos horticultores, que decía en su dictamen que no existía "un orden fijo” para el riego de las huertas. A título de remedio provisional previó que se les diera agua según su disposición en el terreno, "siguiéndose una después de otra en el natural curso del agua". ${ }^{11}$ Según las reformas hechas al reglamento en 1884, "toda huerta que tenga derecho al agua deberá tener en la puerta el número progresivo que le corresponda en el turno de los riegos", lo que leemos como un intento de identificar la propiedad y señalar el orden en que debían recibir agua.

Un año antes se había formado el "Padrón general del regadío de las huertas”, al que ya aludimos, que fijó en 459

60 González, Historia del estado de Aguascalientes, p. 101; Espinoza, Ligeros apuntes históricos, geográficos y estadísticos, p. 26.

61 AGMA, H, c. 10, exp. 10. 
el total de las que había en la ciudad. Apenas un poco después de haberse formado este padrón, los horticultores de Triana se quejaron ante el cabildo de esa "disposición o costumbre", "no muy antigua" - precisaban -, según la cual el agua de "su" acequia "pasa a ayudar" a las huertas "de las manzanas del Olivo", en lo cual se empleaban "doce días y muchas veces más", lo cual se traducía en un "grave perjuicio de las nuestras". Según ellos, las huertas del norte se regaban "hasta cada treinta días", mientras que las suyas tenían que esperar sesenta, lo que provocaba que "tanto las viñas como el fruto de los árboles desaparezcan casi por completo". ${ }^{62}$ Hasta cierto punto tenían razón, porque esas huertas estaban al norte del arroyo, no en Triana, y además porque había 250 huertas en su padrón y sólo 209 en el de Texas; pero debe advertirse que las 35 huertas de las manzanas del Olivo eran precisamente un factor de desequilibrio y que regadas con agua de Texas, como se hacía antes, representaban un alivio para su padrón pero una sobrecarga para el de Texas. Además, debido a la diversa extensión de las acequias y el modo de dividir entre ellas el agua, se tenía la creencia de que la de Triana llevaba más agua que la de Texas, lo cual volvía aconsejable esa compensación.

En el seno del cabildo se reconoció que la queja era fundada, pero se argumentó que "el agua del manantial del Ojocaliente ha disminuido bastante" y que era preciso abastecer un crecido número de fuentes y jardines públicos, lo cual impedía "sujetar estrictamente la distribución del agua al reglamento vigente”. Según el regidor que revisó este asunto era necesario reformar el reglamento "para uniformar los

${ }^{62}$ AGMA, $H$, c. 40, exp. 2. 
riegos" y corregir el desequilibrio denunciado por los de Triana. Y efectivamente, en junio de 1884 se hicieron algunas reformas y se dispuso, entre otras cosas, que el riego fuera dado "en riguroso turno $[\mathrm{y}]$ sin preferencia alguna", lo cual no pasaba de ser una buena intención. Aunque se trataba de una reforma a un reglamento vigente, se preveía que el regidor del ramo o una comisión del cabildo, "de acuerdo con los horticultores", formarían "la reglamentación de las huertas" y "un padrón exacto de todas aquellas que tengan derecho al riego". Hasta donde sabemos, esa "reglamentación" adicional no se hizo, ni tampoco se formó un "padrón exacto" que sustituyera con ventajas al existente. ${ }^{63}$

Al no contarse con la tecnología capaz de dividir equitativamente el agua entre las acequias y venderse el riego por tiempo (un real -12.5 centavos - por hora) y no por volumen, es muy difícil saber qué tan bien fundada estaba la queja de los horticultores de Triana. En 1912 el regidor Refugio Nájera decía que los horticultores de Texas y San Marcos se quejaban "con mucha razón de las irregularidades en el servicio de regadíos", pues recibían menos agua por hora y con menos frecuencia que los del barrio de Triana. Supuestamente corría la misma cantidad de líquido por las dos acequias, pero el número de huertas atendido por cada acequia era diferente; también lo era la superficie irrigada y además "la acequia de Texas tiene que recorrer un trayecto más largo que el agua rodada de Triana", lo que tenía por "consecuencia natural" que los riegos se espaciaran y las huertas atendidas por esta acequia recibieran menos agua que las de Texas.

63 AGMA, $H$, c. 16, exp. 43. "Reformas al reglamento de regadíos vigente”, 4 de junio de 1884 . 
Según él, las pruebas de ello estaban a la vista, pues "las higueras de las huertas de Texas y San Marcos [...] por la falta de agua que se ha hecho sentir más en este año que en los anteriores por causa del bombeo, están desprovistas de follaje y no prometen fruto abundante". Todo esto nos ayuda a entender las razones que tuvo el cabildo para regar las huertas de la calle del Olivo con agua de Triana: se trataba de compensar el hecho de que corría más agua por esta acequia. ${ }^{64}$ En realidad, los problemas relacionados con la insuficiencia y falta de oportunidad de los riegos nunca pudieron resolverse satisfactoriamente. Como acabamos de decir, no se contaba con recursos para repartir en forma equitativa el agua entre las dos grandes acequias y sus ramales, ni tampoco para medir la cantidad de agua que se daba a las huertas. Esto último se hacía por tiempo, según las horas pagadas por cada horticultor, aunque nada aseguraba que la cantidad de agua que descargaba la acequia fuera constante. Las huertas se regaron siempre, desde sus orígenes en las postrimerías del siglo Xvi hasta que desaparecieron del paisaje urbano, a mediados del siglo xx, por el método de "inundación", lo que en realidad podía o no suceder, dependiendo del tamaño de la huerta, la cantidad de tiempo que recibía agua y la presión con que descargaba en esos momentos la acequia. Podía anegarse por completo, proporcionado lo que en el siglo XIX se llamaba un "sello de agua", o podía dejar sólo una lámina superficial, incapaz de mantener húmeda la tierra hasta la siguiente tanda de riego.

${ }^{64}$ AGMA, H, c. 383, exp. 16. "Iniciativa del regidor Nájera para que se dé un mejor servicio a los Riegos de las huertas de Texas y San Marcos y acabar con los abusos”, 11 de junio de 1912. 
Una variante del método de inundación era el charqueo, que se cobraba no por horas sino por unidad de superficie, a razón de dos reales ( 25 centavos) por solar $\left(1756 \mathrm{~m}^{2}\right)$, según una costumbre que databa seguramente de la época colonial tardía, cuando se construyó la acequia de Texas, que era la única que proporcionaba esta clase de riegos. En el primer reglamento de regadíos que se formó (1863) se alude al "orden" a que estaban sujetos "todos los charqueos de Texas", lo que sugiere que se trataba de un derecho adquirido por algunos huerteros, que se fue heredando de generación en generación y que no era fácil abolir de un plumazo. Este método suponía mayor gasto de agua, como se infiere del artículo 2 del reglamento de regadíos de 1899, que concedía "el riego llamado de charqueo" a las huertas inmediatas a la acequia de Texas, "en la inteligencia de que las que [...] puedan regarse sin emplear este medio" se sujetarían a los turnos normales. ${ }^{65} \mathrm{Un}$ poco antes, en 1896, alegando que no le parecía “justo", el regidor Evaristo Femat había logrado que se elevara la cuota a 36 centavos por solar (el equivalente a poco menos de tres reales). ${ }^{66}$ Según el padrón que formó Femat había "cuarenta individuos que tienen derecho al charqueo del agua de la acequia de Texas", dueños en total de 24 solares (5 ha). Con el aumento, la recaudación pasó de 5.99 pesos en cada tanda de riego a 9.15 pesos, según hizo constar el puntilloso regidor. ${ }^{67}$

Se consideraba que una huerta requería riego cada dos meses, aunque era muy frecuente que el servicio se espa-

65 AGMA, $H$, c. 5, exp. 41.

66 AGMA, $A C D, 1896$, acta núm. 6, p. 21v.

67 AGMA, $H$, c. 225, exp. 15. 
ciara más, lo que provocaba que los árboles frutales dieran poco fruto, pequeño y de mal gusto. El servicio de riego se daba a lo largo de todo el año, aunque la demanda disminuía mucho durante la época de lluvias (junio-septiembre). En ocasiones la abundancia de lluvias volvía completamente innecesarios los riegos; era entonces cuando toda el agua del manantial, salvo la que abastecía las fuentes públicas, se conducía a los estanques, que se llenaban por completo. Por el contrario, el calor del verano incrementaba la demanda, multiplicándose también las quejas sobre la insuficiencia de los riegos, la incompetencia del regidor del ramo, la corrupción supuesta o real de sus ayudantes, la colusión entre algunos propietarios y los encargados de ministrar los riegos y, en general, las deficiencias o limitaciones del sistema. En forma clásica, las crisis de desabasto tenían un carácter cíclico y se presentaban durante el estiaje. Las lluvias abundantes, que no eran infrecuentes durante el verano, resolvían milagrosamente todos los problemas, aunque la solución tenía siempre un carácter momentáneo o provisional.

\section{LA DISTRIBUCIÓN DE LOS RIEGOS}

Las dos grandes acequias funcionaban de manera simultánea todos los días y a lo largo de todo el año, lo cual quiere decir que cada una suministraba un máximo de 24 horas de riego en un día, 744 horas en un mes de 31 días y 8760 horas en todo el año, 17520 horas entre las dos. Si el riego no se suspendiera nunca y el agua fuera repartida en forma completamente equitativa entre las 459 huertas que había en la ciudad según el padrón de 1883, cada una de ellas recibiría 38 horas de riego en el año, poco más de seis horas de agua en cada 
turno, suponiendo un intervalo de sesenta días (dos meses) entre cada tanda de riego.

En el valle de Aguascalientes la precipitación pluvial promedio es del orden de $500 \mathrm{~mm}$ anuales, pero hay que tener en cuenta que las variaciones entre un año y otro son fuertes y en no pocas ocasiones, dramáticas; como dijo mucho después un gobernador, de cada diez años "tres son regulares, dos buenos y cinco malos". ${ }^{68}$ Según los registros que hizo el ingeniero Miguel Velázquez de León en su estación climatológica de la hacienda de Pabellón, unos $35 \mathrm{~km}$ al norte de la capital del estado, en 1870 se acumularon $841 \mathrm{~mm}$, pero al año siguiente sólo $372 \mathrm{~mm}$, menos de la mitad. Durante el quinquenio que abarcan sus registros (1869-1873) la media anual fue de $532 \mathrm{~mm}$. Además, la distribución de la lluvia a lo largo del año también es muy desigual. El estiaje es habitualmente muy riguroso y prolongado, pues casi no llueve desde principios de octubre hasta fines de mayo. En contrapartida, los meses de junio, julio, agosto y septiembre son a veces muy generosos en términos de lluvias. En septiembre de 1869 cayeron $206 \mathrm{~mm}$, poco más de la tercera parte de lo que llovió en todo ese año. El de 1871 fue un año muy seco, pero el patrón se repitió, pues en junio cayeron $121 \mathrm{~mm}$, $32 \%$ del total anual. ${ }^{69}$ Un agravante adicional es el carácter torrencial de las lluvias, pues el agua no cae en forma de brisa suave, dando tiempo a la tierra para que la absorba, sino violentamente, lo que provoca grandes avenidas, el desborde de

${ }_{68}$ AHEA, SGG, c. 461, I-A. “Alberto del Valle al presidente Manuel Ávila Camacho solicitando ayuda para llevar a cabo obras de irrigación en las comunidades del estado", 17 de enero de 1941.

69 "Lluvias medidas en la hacienda de Pabellón durante los años que se expresan”, El Republicano (19 mar. 1874). 
los cauces naturales, deslaves, inundaciones, etc. No es infrecuente que durante una sola tormenta, en el lapso de unas cuantas horas, caigan $100 \mathrm{~mm}$ o más, la quinta parte de todo lo que llueve en un año "normal".

La inestabilidad del régimen pluviométrico se reflejaba en forma directa en el comportamiento de los riegos que se daban a las huertas. Aunque no conocemos los registros correspondientes a los años que cubren las mediciones de Velázquez de León, podemos estar seguros de que durante julio y septiembre de 1869, junio, agosto y septiembre de 1870 y junio de 1871 los huerteros no compraron agua de las acequias, pues estuvieron más que bien abastecidos con la que cayó del cielo. En 1872, en cambio, debió haber grandes presiones sobre el sistema, pues el año en general fue seco y el verano pobre en lluvias, sin un solo mes en el que se acumularan siquiera $100 \mathrm{~mm}$ de precipitación.

No conocemos las mediciones que hizo Velázquez de León en 1874, pero, basados en lo que produjo el ramo de regadíos, podemos estar seguros de que las lluvias fueron escasas en agosto y mejores en septiembre. Esos mismos registros nos permiten afirmar que en 1884 llovió poco y que el verano fue tórrido; durante julio y agosto la acequia de Triana produjo 93 pesos, lo que quiere decir que estuvo trabajando al 100\% de su capacidad los 31 días de cada uno de esos meses, sin una sola hora muerta. Las lluvias llegaron en septiembre, mes durante el cual la acequia de Triana trabajó a $18 \%$ de su capacidad y la de Texas a $23 \%$. En términos de las horas de riego proporcionadas, puede decirse que en 1874 el sistema funcionó a $73 \%$ de su capacidad y en 1884 a $85 \%$, cerca de su límite. 
Como el agua se vendía a razón de un real por hora de riego, cada acequia producía al erario municipal un máximo de 24 reales diarios (tres pesos) y un máximo de 1095 pesos al año, 2190 pesos entre las dos. Entre 1870 y 1898 el producto del ramo de regadíos giró en torno de 1750 pesos anuales, lo que significa que las acequias trabajaban a $80 \%$ de su capacidad. Siempre fue más productiva la de Triana, no porque llevara más agua, cosa que en realidad no se sabía a ciencia cierta, sino porque atendía más huertas (250) que de la de Texas (209). En la época había una idea exagerada de la importancia que tenía el ramo de regadíos para las finanzas públicas municipales, lo que explica expresiones como la del regidor Epigmenio Parga, que en enero de 1876 dijo que era "uno de los arbitrios de más importancia". ${ }^{70}$ La verdad es que su peso relativo era modesto y vino a menos con el paso de los años, en la misma medida en que se robustecieron las finanzas municipales. En 1861 las huertas pagaron 1465.81 pesos por concepto de riego, equivalentes a $6.5 \%$ de los ingresos municipales. ${ }^{71}$ En 1873 el ramo produjo casi exactamente lo mismo, pero su peso en el total había disminuido a $4.88 \%$ y el declive continuó hasta fines de siglo. En 1899 se hizo un ajuste de $54 \%$ en la tarifa del riego, elevándolo a 20 centavos por hora, ${ }^{72}$ lo cual llevó hasta 3103 pesos la captación. Sin embargo, su aportación a las finanzas municipales siguió siendo pobre: $3.02 \%$ en 1899 y sólo $1.23 \%$ en 1906, promediando $2.05 \%$ en el periodo 1897-1910.

\footnotetext{
70 AGMA, $H$, c. 38, exp. 6.

71 Epstein, Cuadro Sinóptico de Aguascalientes, 1861.

72 "Plan de gastos y arbitrios del municipio de Aguascalientes para el año 1899”, El Republicano (4 dic. 1898).
} 
Las 24 horas de riego que cada acequia vendía diariamente podían asignarse a uno solo o a varios huerteros, dependiendo de la merced que disfrutaban, el tamaño de los predios y sobre todo su solvencia. El costo del riego tenía que pagarse de inmediato, de manera que sólo con dinero contante se podía acceder al agua. La mayoría de las huertas eran pequeñas y sus propietarios pobres, que compraban apenas unas pocas horas de riego. El jueves 7 de mayo de 1874, por ejemplo, el agua de Triana se repartió entre 6 huerteros, uno de los cuales compró sólo una hora y media de riego. Pero a su lado había un puñado de propietarios ricos, capaces de comprar días completos de riego. En 1874, por ejemplo, fueron atendidas 783 personas, de las cuales 40 contrataron 10 o más servicios. La mayoría pagaron 5 servicios o menos, de pocas horas cada uno, y podemos suponer que lo hicieron así porque no podían pagar más. La información disponible sugiere que la mayoría de las huertas eran cultivadas directamente por sus propietarios, aunque también había un número no despreciable de arrendatarios. Puede suponerse que estos últimos no eran horticultores por razones sentimentales ni estaban embelesados, como dice Correa, por "la alegría de las arboledas", sino individuos que "no tienen más arbitrio para vivir que el cultivo y la explotación de sus árboles frutales", pobres para los que una mala cosecha significaba "una pérdida irreparable". ${ }^{73}$

Entre los propietarios ricos podemos citar a Darío Rangel, que contrató 38 servicios a lo largo de 1874 y recibió un total de 408 horas y media de riego, por las que pagó 51 pesos y medio real. En 17 ocasiones compró 10 o más horas de rie-

${ }^{73}$ El Clarin (14 oct. 1911). 


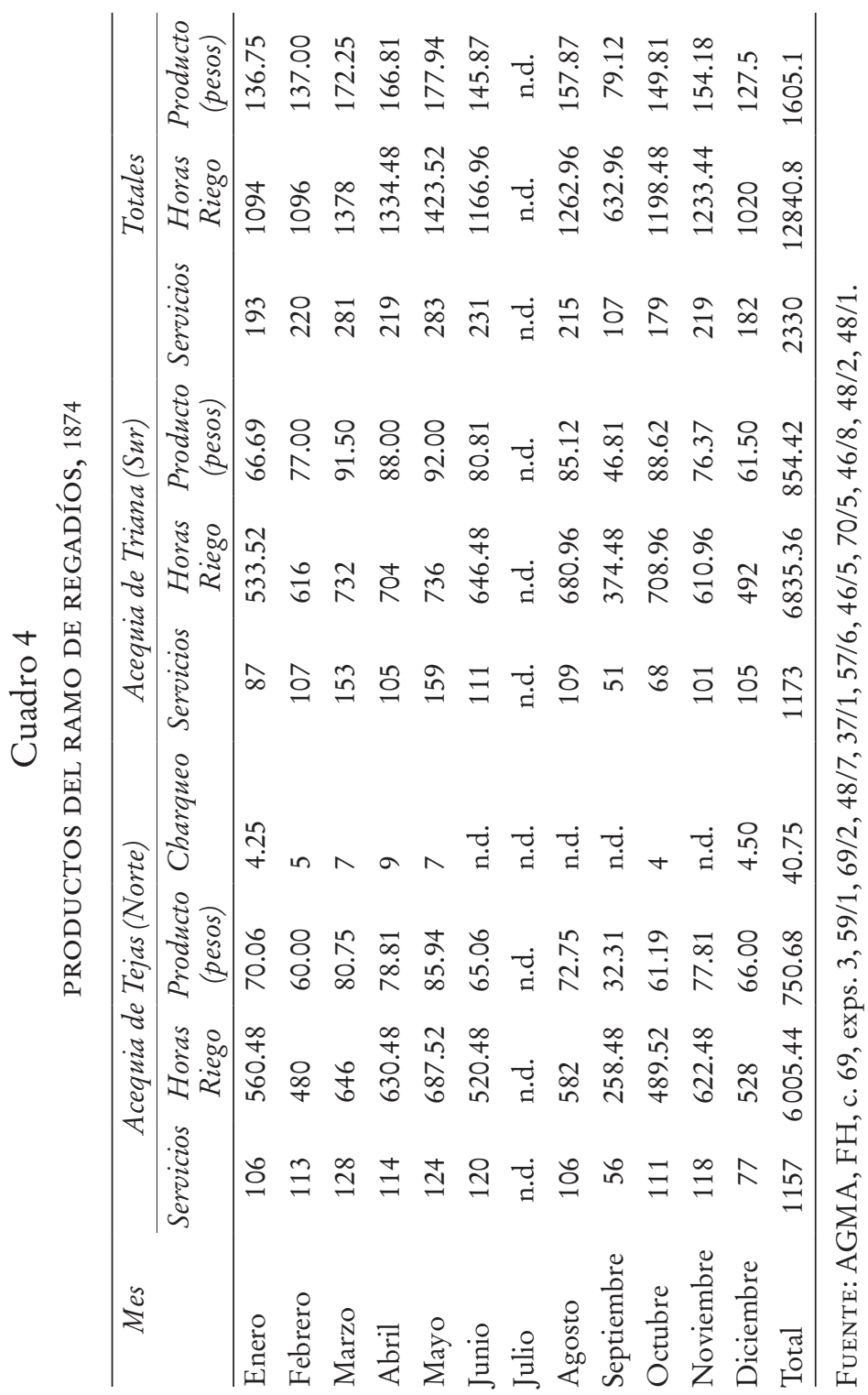


go, y hubo 4 días en los que la acequia de Texas sólo descargó agua en su plantío. Si la mayoría de los propietarios recibía un riego cada 60 días o más, a él sólo le faltó agua en julio y en septiembre, y eso posiblemente porque la lluvia volvió innecesarios los riegos. Durante el periodo más crítico del estiaje su huerta no careció de agua, pues contrató 6 servicios en abril y 5 en mayo, en total 65 horas y media de riego. Mientras en muchas huertas el fruto de los árboles se secaba, en la suya, como dice Correa, el agua gorgoriteaba en los surcos, maduraban los higos y los naranjos, la yedra formaba "túneles de esmeralda" y la frescura acariciaba "como mano de hada". ${ }^{74}$

Otro huertero rico era Antonio Boneta, un fraile franciscano "pequeñín, bullicioso y dinámico", de cuyas andanzas se ocupa Correa con cierto detalle. Originario de Puebla, había empezado a estudiar medicina en la ciudad de México, pero una decepción amorosa lo hizo entrar al convento. "Entre la clase menesterosa, a la que socorre con largueza”, tenía fama como curandero, aunque el único remedio que conocía era la hidroterapia, con la que combatía "cualquier dolencia". Era asiduo en los mentideros de las trastiendas, a los que acudía "a pedir por sus pobres" y donde era recibido "con beneplácito". En cuaresma observaba el ayuno "con rigor", pues hacía una sola comida, "aunque famosa por el número y la calidad de los platillos"; entre otras cosas "chiles de tal modo rellenos que se sabe que lo son por la punta del rabo que se les ve". En San Diego, el templo al cuidado de los de su orden, daba todas las noches "un ejercicio piadoso", pero

\footnotetext{
${ }^{74}$ AGMA, H, c. 69, exp. 3. "Cuenta de lo producido del ramo de Regadíos en 1874.” Correa, Un viaje a Termápolis, p. 133.
} 
hablaba en forma tan rápida y atropellada que "sólo se le entienden las primeras y las últimas sílabas”. En medio de sus rezos dejaba el púlpito y se iba al Parián a recorrer puestos y tiendas, "charlando con cualquier amigo o jugando ajedrez". Volvía a la iglesia "cuando ya las beatas roncan, si no es que se han ido cansadas de esperar". ${ }^{75}$

Según Correa, la verdadera ocupación del padre Boneta era la "engorda de marranos", de la que sacaba "dinero con que hacer sus caridades". No tenemos forma de verificarlo, pero el dato sugiere que las huertas no eran necesariamente esos plantíos de viña, morera y árboles frutales que preveían los reglamentos, sino que en realidad sus propietarios tenían un buen margen de maniobra para dar a esos terrenos alguna otra ocupación, sin perder por ello el derecho al riego. El padre Boneta, por ejemplo, compró agua en 12 ocasiones a lo largo de 1874, un total de 179 horas. Su huerta o zahúrda se ubicaba en la manzana del Plan y era una de las mejor regadas en la ciudad. ${ }^{76}$

$$
\text { ¿“EL JEREZ DE MÉXICO”? }
$$

En el capítulo que Correa dedica a las huertas de la ciudad, notable por sus efusiones líricas, se echan de menos las alusiones al cultivo de la vid. Esta parquedad, a la que se añade la de otras fuentes, contradice esa tradición nunca bien documentada pero muy gustada que hace de Aguascalientes un lugar de grandes y espléndidos viñedos. Desde luego, ya

75 Correa, Un viaje a Termápolis, pp. 165-170. Lo menciona también un par de ocasiones en Viñetas de Termápolis.

76 AGMA, H, c. 69, exp. 3. "Cuenta de lo producido del ramo de Regadíos en 1874.” 
estaban lejos los días en que el recaudador de alcabalas Jacinto López Pimentel había intentado (sin éxito) convertir su "extensa heredad" en una gran fábrica de vinos y aguardientes. En 1844 se decía que en las huertas de la ciudad se cultivaba viña "de buena clase y de varias calidades", negra, blanca y moscatel legítima. ${ }^{77}$ Hacia 1880 se conservaba el gusto por los patios emparrados en las casas del centro de la ciudad, en los que colgaban "apretados racimos de uvas negras" ${ }^{78}$

La verdad es que en la época porfiriana el tequila de Jalisco, el mezcal de Pinos, el pulque de los llanos de Ápam y la cerveza, debido a su baratura, competían ventajosamente y en todo el país con el vino y los aguardientes de uva, cuya producción tenía pocos estímulos y menos consumidores. En 1871 el joven caricaturista José Guadalupe Posada inmortalizó al gobernador Jesús Gómez Portugal no sólo como un traidor al presidente Juárez, sino también como un bebedor contumaz de Pinos, del que lleva una botella en la faltriquera de su saco, lo cual implicaba cierto desprecio por los vinos de la tierra. ${ }^{79}$ Díaz de León escribió en 1891 que el pulque era "la cerveza de nuestra clase de pobre", aunque en verano se consumía también mucho colonche, un "agradable" vino de tuna cardona que se acostumbraba derramar ritualmente sobre la ropa. ${ }^{80}$ Tan sólo en algunas regiones norteñas se

\footnotetext{
77 BSHGEA, t. I, núms. 7, 8 y 9, 1935, p. 13. "La industria y la agricultura en 1844. Copias de los documentos que se citan en la Memoria presentada al Supremo Gobierno por la Dirección General de la Agricultura e Industria Nacional relativa al año de 1844."

${ }^{78}$ Pani, Ayer, p. 176.

79 El Jicote (18 jun. 1871).

${ }^{80}$ Díaz de León, “Apuntes para el estudio de la higiene”, p. 220; Correa, Un viaje a Termápolis, p. 153.
} 
CARICATURA DEL GOBERNADOR GÓMEZ PORTUGAL

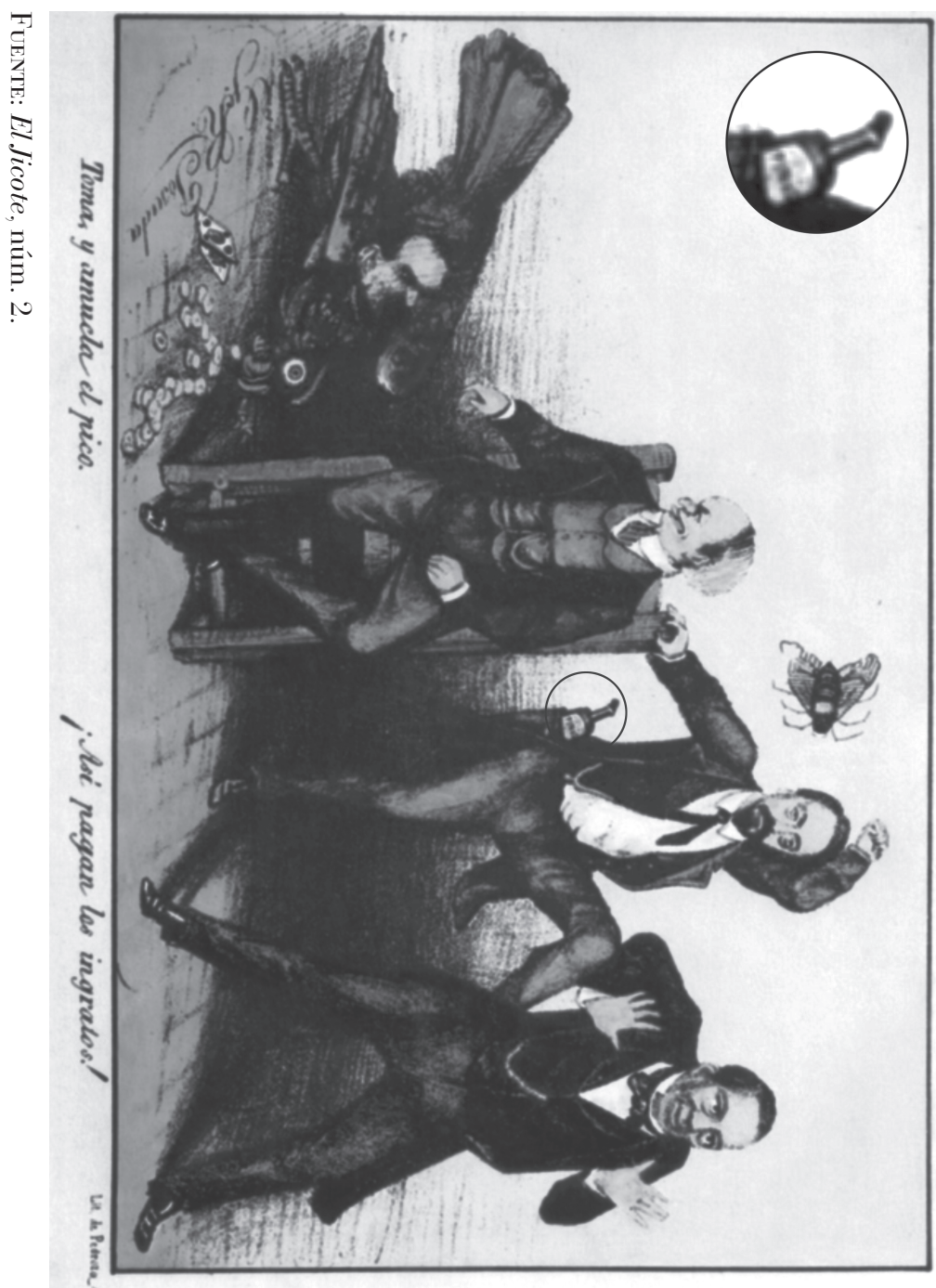


impulsó seria y sistemáticamente la producción de vino para mesa; en Parras, que tenía una larga tradición en ese campo, se amplió la capacidad de las bodegas, se introdujeron nuevas técnicas y se logró la aclimatación de cepas mejores y más resistentes a las plagas. ${ }^{81}$

En Aguascalientes el cultivo de la vid y la fabricación de vinos y aguardientes de uva tenían un carácter muy modesto, a pesar de lo cual se afirmaba que constituían uno de los principales ramos de la riqueza pública. Entre 1885 y 1886, debido a los esfuerzos del Ministerio de Fomento, supuestamente se sembraron miles de sarmientos de vid en las huertas de la ciudad de Aguascalientes y en diversas haciendas del estado. Un técnico del Ministerio “se mostró en extremo complacido de la forma en que se emprendía este nuevo esfuerzo para reivindicar y ampliar nuestra vieja tradición vitivinícola" y dejó instrucciones relacionadas con "el cuidado de las plantaciones”. Se dijo que “más de un 60\% de los sarmientos plantados se habían logrado” y se vaticinaba "que se obtendrían abundantes frutos" ${ }^{82}$ Con evidente exageración se afirmaba que en todo el estado estaban plantadas unas 500000 cepas, "cuyo número debe aumentar sin duda año con año, a juzgar por el empeño y constancia con que los dueños de viñedos procuran su fomento y propagación". ${ }^{83}$

Según recuentos oficiales, había por lo menos 12 pequeñas bodegas empeñadas en la fabricación de vinos, entre las que destacaba la de Salvador Pérez, cuyos vinos, hechos con "gran escrupulosidad”, eran "muy a propósito para administrarlos

81 Cosío Villegas (dir.), Historia moderna de México, p. 360.

82 Topete del Valle, “La vid y el vino en Aguascalientes”, p. IV.

83 "El cultivo de la viña en el Estado”, El Republicano (25 abr. 1886). 
a los enfermos y a los convalecientes" ${ }^{84}$ En la Exposición de Artes e Industria de 1886, Pérez fue premiado con una medalla de plata "por las diversas clases de vinos de su fábrica". ${ }^{85}$

El gobierno trató de alentar a los fabricantes de vinos con decretos que los exceptuaban del pago de diversos impuestos, con la condición de que la producción anual de cada fábrica "sea de más de treinta barriles y que su elaboración no sea hecha por el sistema de concentración por medio del fuego". ${ }^{86}$ Hijo de españoles, el gobernador Francisco G. Hornedo (1877-1879 y 1883-1887) creía que se trataba de un negocio de gran porvenir, lo cual explica las exenciones y facilidades que dio a los productores. Aunque reconocía que los vinos locales eran apenas de "regular calidad", obtuvo diversas franquicias del Ministerio de Fomento e hizo traer de Europa sarmientos de la mejor clase; con el tiempo, decía, ese ramo de la industria sería "el principal de la riqueza pública" ${ }^{87}$ Ello demuestra que no eran pocas ni insignificantes las personas que compartían los sueños delirantes de un Agustín R. González, que en 1881 escribió que "Aguascalientes está llamado a ser el Málaga, el Jerez de México”; según él, los viñedos debían extenderse hasta "cubrir una gran extensión de nuestro territorio", como lo aconsejaba "la excelente uva que ostentan las huertas de la capital". 88

Sin embargo, la opinión de los conocedores era muy diferente. Luis Eirale, inspector del Ministerio de Fomento, visitó en septiembre de 1887 algunos viñedos de la locali-

\footnotetext{
${ }^{84}$ El Instructor (15 oct. 1886), p. 8.

${ }^{85}$ El Republicano (6 mayo 1886).

${ }^{86}$ Decreto 417 de la legislatura, El Republicano (11 jul. 1886).

87 Hornedo, Memoria, p. xiv.

${ }^{88}$ González, Historia del estado de Aguascalientes, pp. 304-305.
} 
dad "con el objeto de enseñar a los vinicultores a fabricar sus vinos bajo el procedimiento práctico europeo de la fermentación". Para comenzar, encontró que la uva se había perdido en su mayor parte "a causa de las continuas lluvias", por lo que sólo se habían cosechado 6000 arrobas $(69000 \mathrm{~kg})$, de tamaño muy pequeño, manchadas y ácidas, "circunstancias que resolvieron a los productores a realizar su escaso fruto al ínfimo precio de diez y doce reales la arroba". En otras palabras, el cultivo de la vid distaba de ser un buen negocio. De todas formas, decía Eirale, las pérdidas serían menos cuantiosas si los cosecheros fueran "más cuidadosos con sus plantíos”, pues casi todos tenían la nociva costumbre de

[...] hacer siembras de maíz, fríjol y otras plantas en la temporada lluviosa, en los surcos y huecos de sus viñedos, impidiendo por este torpe medio la penetración del sol y la ventilación, que son elementos indispensables a la buena vegetación y a la madurez de los frutos, y que naturalmente causan el empobrecimiento del suelo, sucediendo a la vez que el enfriamiento y la humedad en las tierras se prolongan por falta de sol vivificador, las vides sufren considerablemente por la opresión en las que las tienen otras plantas extrañas, sufriendo castigos los propietarios como fruto de su reprochable proceder, creyendo que unos cuantos almudes de semillas de poco valer que cosechan pueden aumentar en algo sus productos. ${ }^{89}$

Es interesante advertir que este abigarramiento era precisamente lo que había cautivado a Correa, quien observó en las huertas de la ciudad esas viñas "que con sus follajes tienden luengos palios de sombra, de donde colgarán los racimos

${ }^{89}$ Eirale, “Informe sobre el cultivo de la vid en Aguascalientes", pp. 3-4. 
apretados de las uvas, granos de oro y de ámbar, gotas de púrpura o perlas negras". ${ }^{90}$ Pero el enviado del Ministerio de Fomento era un técnico, no un lector de literatura romántica, veía las cosas de otro modo y comparaba en muy malos términos esos miserables tablones con los magníficos viñedos de Parras, en los que se cultivaba uva de excelente calidad, a partir de los cuales se hacían vinos que competían airosamente con los europeos.

Obviamente estas descortesías fueron ignoradas en Aguascalientes, donde siguió hablándose de los progresos "verdaderamente notables" que registraba el cultivo de la vid, lo que permitía albergar risueñas esperanzas. También se dijo que el Ministerio de Fomento había distribuido "más de 200000 sarmientos de vid entre las personas que los han solicitado". ${ }^{91} \mathrm{Y}$, aunque se reconocía en sordina que la industria vinícola no alcanzaba aún "todo el esplendor de que es susceptible", se ponderaban con entusiasmo los vinos que salían de las fábricas de los hermanos Medina, el señor Audinot y el ya mencionado Salvador Pérez. En esta última, que era la más importante, se fabricaban anualmente 150 barriles de vino, "que por su buen gusto y excelencia compite con los que nos vienen del extranjero", teniendo la ventaja añadida de su bajo precio, "que lo pone al alcance de todas las fortunas". ${ }^{92}$ La verdad es que el vino que se hacía era bastante mediocre, bueno tan sólo para consagrarlo en misa o administrarlo como remedio a los enfermos.

90 Correa, Un viaje a Termápolis, pp. 127-135.

${ }^{91}$ El Republicano (26 feb. 1888).

92 "La industria vinícola”, El Republicano (26 jul. 1891). 
En las huertas de la ciudad, como lo constató el implacable inspector Eirale, los viñedos se disputaban la tierra y el agua con los árboles frutales e incluso con las siembras de maíz y frijol. Los viñedos eran pequeños y en realidad no sabemos de una sola huerta que estuviera exclusiva y metódicamente dedicada al cultivo de la vid. En 1887 Arnulfo Díaz de León obtuvo cinco horas de riego para regar un viñedo de "poco más de 3000 cepas" que tenía en su huerta de la calle de San Juan Nepomuceno. ${ }^{93}$ El cura Isidro Navarro, por su parte, consiguió 32 horas de riego para regar "un viñedo de más de 16000 cepas" que plantó en su huerta de La Salud. ${ }^{94}$

$\mathrm{El}$ intento más ambicioso que tenemos documentado es el de Juan Gámez y Manuel Aranda, quienes en 1891 plantaron "cepas de uva española, californiana, moscatel y las mejores del país" en un extenso potrero o huerta del barrio de La Salud. Según ellos, el terreno que estaban sembrando "tiene capacidad para 200 a 300000 cepas, que nos proponemos plantar", lo que sin duda constituiría "la primera y más extensa [viña] en el territorio del Estado”. Además, querían establecer una fábrica de vinos, en la que encontrarían trabajo numerosos operarios y que daría nuevo impulso a esa decaída industria. Sin embargo, como no contaban con agua suficiente para los riegos, muchas cepas se secaron y les quedaron sólo 20000 , la décima parte de las anunciadas. A pesar de ello y de la activa oposición de la mayoría de los horticultores de Triana, obtuvieron una concesión en verdad extraordinaria de "cien horas de riego en cada turno". ${ }^{95}$ Pero

\footnotetext{
93 AGMA, H, c. 138, exp. 2.

94 AGMA, H, c. 138, exp. 4.

${ }^{95}$ AGMA, $H$, c. 184, exp. 16.
} 
tampoco así pudo consolidarse ese viñedo, que seguramente no pasó de ser uno de esos "tablones” que fascinaban a los temperamentos románticos como Correa, pero eran muy criticados por los técnicos.

Mucho tiempo después, durante el sexenio de Miguel Alemán (1946-1952), el secretario de Agricultura, Nazario Ortiz Garza, visitó por razones de trabajo la ciudad de Aguascalientes y de paseo por el barrio de Triana alguien le obsequió "un ramo de uvas bonitas, de la variedad cornichón, de atractivo color, pero que estaba enfermo". Intrigado, el funcionario averiguó que las uvas procedían de una huerta del barrio, que se daban en una parra silvestre, muy vieja, que se había salvado de la destrucción supuestamente ordenada desde Madrid para proteger el comercio de vinos importados. "Si esta parra, abandonada y descuidada, puede dar este fruto, ¿qué sería en mis manos?”, se preguntó. Entusiasta de "las labores del campo" y dotado de las relaciones políticas y los medios económicos apropiados, compró el rancho de Chicalote, en las afueras de la ciudad, y sembró miles de hectáreas de viñedos en tierras según él "vírgenes, semidesérticas”, replicando la experiencia de los viñedos de Parras, que por "su hermoso aspecto y gran producción" eran "los mejores de la república”. En 1953, "cuando iniciaba con todas mis fuerzas la formación de los viñedos”, se hizo valer de su amistad con el presidente Ruiz Cortines y el secretario de Hacienda Carrillo Flores para lanzar al mercado dos emisiones de certificados de crédito, de cuya venta obtuvo el dinero con el que capitalizó su naciente y próspera negociación. Sin duda, el acceso en gran escala a los recursos públicos fue una clave muy importante del éxito que alcanzó su industria. Con vanidad mal disimulada, él mismo dice que 
gastó más de 1000000 de pesos en la formación de su viñedo en una época en la que el gobierno del estado de Aguascalientes "tenía un presupuesto de 700000 pesos" anuales. Y en sus manos, efectivamente, los viñedos de Aguascalientes tuvieron "un gran futuro": mejoró las tierras, sembró decenas de miles de sarmientos que hizo traer "de nuestros viñedos de Saltillo" y de Europa, obtuvo agua de pozos profundos, reguló con mucho cuidado los riegos y procedió metódicamente en todo, hasta que al cabo de algunos años logró cosechar grandes cantidades de uva, con la que hizo su famoso brandy San Marcos, que según la publicidad contenía "siete kilos de uva en cada botella". El presidente Ruiz Cortines, que siempre fue "muy zalamero", describió a Nazario Ortiz Garza como "un gran hombre, un mexicano ejemplar, un patriota a quien respetamos por su honradez y su trabajo"; fue este personaje, valido de estas amistades, quien constituyó la Compañía Vinícola de Aguascalientes, a la que en buena medida se debe el éxito espectacular que tuvo la vitivinicultura en Aguascalientes a partir de 1950, el hecho de que este pequeño estado se convirtiera durante algunas décadas en uno de los principales productores de uva en el país, "el Málaga o el Jerez de México", como había soñado o profetizado Agustín R. González. El éxito fue tan rutilante que "contaminó" la historia del lugar, por así decirlo, dando pábulo a la leyenda según la cual Aguascalientes fue desde la época colonial un lugar donde la vid se cultivó por extenso y se hicieron buenos vinos y aguardientes. ${ }^{96}$

96 Ortiz Garza, Remembranzas, pp. 137-146. El verdadero detonador del cultivo de la vid a escala industrial fue la Comisión Nacional de Irrigación, que en 1932, aprovechando la reciente construcción de la presa Calles, formó un pequeño “viñedo experimental” en Pabellón; en 1937, 


\section{REGLAMENTOS DE REGADÍOS}

La gestión del sistema de riego estuvo en manos del cabildo desde 1644, cuando el oidor Cristóbal de Torres ajustó con los vecinos de la villa el pago de una composición por el agua del manantial de Ojocaliente. Con el paso del tiempo se fue conformando un corpus de usos y costumbres, como la de cobrar un real por hora de riego, la de regar las huertas en determinado orden ("de abajo para arriba") o la de dar servicio de "charqueo" con la acequia de Texas, pero no fue sino hasta la segunda mitad del siglo xIX cuando se redactaron reglamentos en toda forma. Lo mismo que en otros muchos lugares, estos reglamentos tenían el propósito evidente de ordenar y alentar la horticultura. ${ }^{97}$ Estos documentos son un reconocimiento de la importancia que tenían las huertas en la economía del lugar y en la organización del espacio urbano, pero pueden leerse “al revés” y proporcionarnos una radiografía del tema, de los problemas que tenías los huerteros y de las dificultades relacionadas con la gestión del agua. En forma muy clara permiten advertir que en el curso de la segunda mitad del siglo XIX el agua fue perdiendo su "vocación" original (el riego de las

a instancias del gerente del Distrito de Riego 01, se plantaron 450 ha de vid con variedades importadas de Estados Unidos, ejemplo que fue seguido por algunos rancheros, incluido el gobernador Jesús María Rodríguez (1944-1950), que fue quien invitó a Ortiz Garza a compartir sus experiencias como cultivador de vid. Topete Del VAlle, "La vid y el vino en Aguascalientes”, pp. i-ix. Con poco más de 9000 ha de vid, en 1980 el estado de Aguascalientes llegó a ser el segundo en importancia en todo el país, sólo detrás de Sonora, pero por encima de entidades mucho más grandes y que tenían gran tradición, como Coahuila y Querétaro. MEYER, La vitivinicultura en México, láminas 10 y 11.

97 Авоiтes, El agua de la nación, p. 28. 
huertas) y se dedicó de modo creciente a satisfacer necesidades que emergieron junto con el crecimiento de la ciudad, los nuevos hábitos de higiene y, a partir de 1884, el imparable proceso de industrialización. En este sentido conviene reparar en el abismo que separa el título de composición de 1644, en el que se reconocía que el agua del manantial de Ojocaliente pertenecía a los vecinos, los cuales debían ocuparla en "los riegos de las huertas y servicio de sus casas", ${ }^{8}$ y el reglamento de regadíos de 1899, que erigía al cabildo en árbitro incontrastable y la concedía en primer lugar "a los jardines, alamedas y paseos públicos", y sólo en seguida "a los plantíos o huertas de viña, moreras, árboles frutales y hortalizas". 99

El primer reglamento que conocemos data de 1863, consta de sólo 17 artículos y fue redactado por una "comisión de hortelanos" bajo la presidencia del regidor del ramo, lo que puede interpretarse como una señal de que se les seguía tratando como dueños del agua y responsables de su reparto, o por lo menos como gestores solidarios al lado del cabildo. ${ }^{100}$ No hacía mucho (1854), 40 hortelanos habían declarado ante escribano que en su carácter de "dueños y poseedores del agua del Ojocaliente, que está dedicada a los regadíos de las huertas", estaban preocupados porque el ayuntamiento "piensa darle otra dedicación [...], aplicándola a fuentes o pilas de las plazas públicas" ${ }^{101}$ Este episodio constituía apenas un aviso de que se estaba operando un cambio en la

98 Gómez Serrano, "Una historia escrita con tinta de agua”, p. 45.

99 AGMA, $H$, c. 5, exp. 41. Sección Gráficos e Impresos.

100 El manuscrito, con tachones y de lectura difícil, se conserva en AGMA, $H$, c. 38 , exp. 8 .

101 AHEA, PN, ff. 123-126, 1854. Pablo González Hermosillo. El énfasis es mío. 
relación entre los hortelanos y el cabildo, sobre todo una ampliación de las facultades de éste respecto a la administración del agua.

Este reglamento es básicamente una condensación de los usos y costumbres relacionados con la gestión del agua de Ojocaliente y el riego de las huertas de la ciudad. Preveía la sanción de abusos bien conocidos, como la desviación del curso de las acequias y la morosidad en el pago de los derechos de agua. Es en particular interesante la cláusula sobre los que cortaban "clandestinamente" los riegos, "con anuencia del aguador", porque quiere decir que no era raro que los huerteros se coludieran con los funcionarios municipales. El único espacio público al que se daba agua era el jardín de San Marcos, construido en la década de 1830, pero más importante desde 1848, cuando se convirtió en sede de la feria anual de comercio, a la que a partir de entonces dio nombre y fechas. Por razones de higiene pública se regulaba el horario en que se abastecerían las fuentes públicas y, sobre todo, se prohibía "dar agua" al cementerio que había a un costado del santuario de Guadalupe.

Este reglamento fue reformado en 1874 por el congreso del estado, hecho que constituye en sí una primera novedad, nada despreciable, pues quiere decir que el tema ya no estuvo completamente en manos del cabildo y que los huerteros habían perdido el control del manantial de Ojocaliente, que todavía detentaban en 1863. Aunque no se les negaba el riego, se preveía la desaparición "de las huertas comprendidas en las calles céntricas de la población”, a cuyos dueños se indemnizaría con los fondos "sobrantes" de la tesorería municipal; se esgrimían como razones "la molestia que resulta a los transeúntes con los bordos que es preciso levantar 
para introducir el agua" y el estancamiento consiguiente, el cual "es nocivo a la salud pública". No hubo indemnizaciones, pero la previsión es interesante y se inscribe en ese largo proceso de reapropiación del casco histórico de la ciudad, marcado por el retraimiento de las huertas y el ascenso del uso residencial y comercial del suelo. ${ }^{102}$

En general, este reglamento tiene un carácter menos pasivo que el de 1863 . No se limita a recoger usos y costumbres, sino que trata de reorientar y mejorar la práctica de la horticultura, estimula algunos cultivos (el olivo y la morera), le concede nuevas atribuciones al juez de las aguas y trata de conciliar la horticultura con el riego de "alamedas, jardines públicos y paseos", que no tenían una función productiva sino recreativa, y que además eran espacios públicos, no privados como las huertas.

En cuanto a la intervención del congreso del estado y del jefe político del partido de la capital en la confección y promulgación del reglamento, el tema se inscribe en un proceso más amplio y complejo, que tiene que ver con el sometimiento del cabildo y la disminución de sus facultades en provecho del gobierno del estado. El cabildo, de hecho, se sentía sometido "a una especie de pupilaje" que no justificaban las costumbres ni las leyes. Como recuerda Delgado, en 1872 el gobernador Ignacio T. Chávez había impuesto como jefe político a Salvador Correa (padre del escritor y protagonista del viaje a Termápolis) y en su encaprichamiento llegó al extremo de asumir la presidencia del ayuntamiento. ${ }^{103}$ Como dice Guerra, "el

102 Reglamento de Regadíos, 1874; AGMA, H, c. 27, exp. 6; AGMA, $H$, c. 38, exp. 8, 1874. Se publicó también en el Boletín Municipal (31 jul. 1874).

103 Delgado Aguilar, Jefaturas políticas, pp. 53-59. 
mejor criterio para juzgar la autonomía de los municipios es la existencia de jefes políticos", funcionarios dotados "con poderes muy amplios" y capaces "de dirigir toda la vida política y administrativa de los municipios de su circunscripción”, ${ }^{104}$ lo que se pone de manifiesto en esta nueva forma de reglamentar el riego de huertas en la ciudad de Aguascalientes, apenas un pequeño capítulo en esa historia larga y compleja que tiene que ver con la pérdida de facultades del cabildo.

El reglamento de 1874 sufrió algunas modificaciones en 1884, de nuevo practicadas por el congreso del estado y comunicadas a la corporación municipal por medio de la jefatura política del partido. ${ }^{105}$ Eran ajustes de detalle, como cambiar la moneda en la que debían pagarse los riegos, 13 centavos por hora en lugar del real establecido antes. El cambio más importante se refiere a la obligación de las huertas de ostentar en su puerta "el número progresivo que le corresponda en el turno de los riegos" y las horas de riego "que puedan invertirse en cada una de ellas”. También se establecía la obligación del regidor del ramo de presentar al cabildo "un padrón exacto de todas aquellas [huertas] que tengan derecho al riego", base sobre la cual la corporación le daría a cada una "su correspondiente justificante", sin el cual no serían regadas. Hasta donde sabemos, nunca se hizo este "padrón exacto" que indicara el número de árboles frutales y parras de cada huerta, lo cual a su vez nos permitiría calcular la potencia productiva del huerto urbano.

Estas reformas fueron incapaces de poner orden en el ramo e impedir los abusos. A fines de noviembre de $1895 \mathrm{el}$

104 Guerra, México: del Antiguo Régimen a la Revolución, t. I, p. 275.

105 AGMA, $H$, c. 16, exp. 43. Reformas al reglamento de regadíos vigente, 4 de junio de 1884 . 
cabildo se quejaba ante el jefe político porque "las manifestaciones hechas por los horticultores" eran inexactas, insuficientes y muchas veces francamente tramposas, lo que implicaba que no concordara "el número de huertas que arrojan dichas manifestaciones" con las que recibían riego. Por esas razones, se le pedía a la jefatura que exhortara de nuevo "a todos los dueños de huertas" para que rectificaran sus manifestaciones sin omitir o falsear datos. ${ }^{106}$ Sólo unas semanas después, el regidor Evaristo Femat propuso algunos cambios que consideraba "indispensables" para el reglamento de regadíos. Como responsable del ramo, conocía de primera mano los problemas, lo que daba autoridad a su diagnóstico, según el cual en el ramo imperaba un "desorden casi absoluto"; había muchos "abusos”, se presentaban en su escritorio "quejas continuas" y los recaudadores enfrentaban "grandes dificultades" para hacer su trabajo, lo cual se traducía en "perjuicios" para las finanzas municipales "y aun [para] los mismos horticultores". Como se infiere de su propuesta, Femat pensaba que los abusos (y robos) se remediarían con un control más estricto de los cobros que hacía el juez encargado de los riegos. Por esa razón propuso que se entregaran forzosamente a los horticultores, en el momento del pago, "recibos con talón, impresos y sellados por la Tesorería Municipal", y que esos recibos indicaran "el nombre de la persona que hace el pago", el número de la huerta beneficiada, "las horas de agua gastadas" y su valor. El talón debería ser una "copia exacta del recibo expedido", el cual sería entregado al regidor del ramo, para que éste, a su vez, entre-

106 AGMA, H, c. 215 , exp. 4. 
gara cuentas pulcras y claras a la tesorería municipal. El pleno del cabildo hizo suya, por unanimidad y "en todas sus partes", la iniciativa del regidor Femat, lo que sugiere que la percepción del desorden y los abusos que había en el ramo estaba generalizada; tal vez era un secreto a voces. ${ }^{107}$

A partir del remedio propuesto se infiere sin muchas dificultades el carácter de la enfermedad que padecía la horticultura, una de ellas al menos. Sin duda, había una escandalosa colusión entre el juez de riegos, sus ayudantes y los horticultores, lo que permitía a éstos obtener agua sin pagarla o pagar menos por la que recibían, y a los funcionarios embolsarse parte de lo recaudado, entregando al regidor del ramo y a la tesorería cuentas "a modo". Siguiendo a Escalante, parece que se trata de un buen ejemplo de esa paradoja característica del Estado mexicano decimonónico: por un lado, su omnipresencia, en este caso por medio de reglamentos cada vez más acuciosos, y por otro su intrínseca debilidad, la inexistencia en la práctica de "una organización jurídica eficiente de las relaciones sociales" y de "un hábito de obediencia". El Estado moderno emergía, en este caso mediante el deseo de normar y mejorar la horticultura, pero sólo la clase política o una parte de ella estaba interesada en el asunto, pues los pequeños funcionarios y los dueños de las huertas "buscaban su espacio en alguna otra parte, en un orden que mantuviera sus privilegios y que aumentara su capacidad para obrar". El regidor Femat denunció el "desorden casi absoluto" que había en la horticultura, pero una mirada más aten-

107 AGMA, H, c. 217, exp. 6. Iniciativa hecha por el C. Regidor Evaristo Femat, proponiendo las reformas que cree indispensables al Reglamento de Regadíos vigente para corregir varios abusos en el ramo, 9 de diciembre de 1895 . 
ta nos revela que el dominio del Estado era precario y las "redes locales" de poder muy capaces de burlarlo o desafiarlo; que hasta cierto punto el orden realmente existente era el de "los caciques y los señores" y que, en suma, el asunto era más complejo de lo que sugiere la normatividad. ${ }^{108}$

Femat era un funcionario muy celoso de su deber y siguió observando con lupa el ramo de regadíos. En diciembre de 1898 le presentó al pleno del cabildo el borrador de un nuevo reglamento, que recogía sus antiguas preocupaciones sobre el "desorden" que imperaba en ese ramo tan sensible y visible de la administración pública. En su proyecto se consolidaba la idea de que el riego de "jardines, alamedas y paseos públicos” tenía un carácter prioritario, yéndole a la zaga el que se concedía a "particulares" dueños de huertas, alfarerías y obras en construcción. También se ponía atención especial en las obligaciones del encargado de "la dirección de las aguas", las cuales se enumeraban con bastante detalle. Las acequias eran igualmente objeto de una atención especial, pues el hecho de que atravesaran numerosas calles e incluso fincas de particulares evidenciaba sus inconvenientes, la imposibilidad de avenirlas con las condiciones de higiene esperables de una ciudad moderna como la que Aguascalientes intentaba ser. ${ }^{109}$

El nuevo reglamento de regadíos, que se publicó en enero de 1899 , recogía las principales preocupaciones del regidor Femat, pero iba más allá en su propósito de normar el

108 Escalante Gonzalbo, Ciudadanos imaginarios, pp. 97-100.

109 AGMA, H, c. 246, exp. 25. "Proyecto del Reglamento que para el Ramo de Regadíos formuló y presentó a la Corporación para su aprobación el C. Regidor Evaristo Femat, por encontrar en el vigente muchas deficiencias”, 7 de diciembre de 1898. 
ramo, hacer más eficiente el uso del agua y conciliar las exigencias de una ciudad característica por sus huertas con las de una urbe sacudida por un intenso proceso de industrialización. Apenas tres años atrás había iniciado sus actividades la Gran Fundición Central Mexicana, que ocupaba más de 1000 obreros, y en 1897 se había contratado con la compañía del Ferrocarril Central Mexicano la construcción de sus Talleres Generales, a la vera de la acequia que iba del manantial a los baños de Los Arquitos.

El nuevo reglamento tenía 34 artículos, exactamente el doble de los que tenía el de 1863, lo que constituye un indicio de las crecientes complejidades del tema y de la voluntad intervencionista del gobierno. Las disposiciones estaban agrupadas en cuatro "capítulos”. El primero se refiere a "la distribución de las aguas" y refrenda que la prioridad la tenían los “jardines, alamedas y paseos públicos”, seguidos, en ese orden, por las huertas, las alfarerías y "las obras públicas y de particulares”. A diferencia de los reglamentos anteriores, no se señalaba el precio del riego, sino que se indicaba que "será el que señale el plan de arbitrios del municipio", lo que dejaba abierta la posibilidad de ajustarlo anualmente, como en efecto se hizo. El segundo capítulo se refería a las acequias y huertas y reiteraba la idea de no dar riego a las huertas que no estuvieran inscritas en el padrón y a las que no tuvieran árboles frutales u hortalizas. La conservación en buen estado de las acequias y los caños "que den entrada o salida al agua" se delegaba en "los dueños o arrendatarios de huertas”; en las calles, el ayuntamiento cuidaría que las acequias estuvieran bien niveladas y revestidas de piedra donde la topografía del terreno lo exigiera. Con el propósito de corregir uno de los principales inconvenientes del método 
de riego empleado se prescribía que "los dueños, encargados o arrendatarios de huertas están obligados a impedir que las aguas que reciben para el riego se filtren sobre las calles en perjuicio de la salubridad y del tránsito públicos”. Se prohibía "bañarse en las acequias, lavar ropa, lana, pieles, etc.; bañar animales y arrojar basuras, escombros y demás objetos que impidan el libre curso de las aguas", lo que en buen romance es un claro reconocimiento de que todas esas cosas se hacían. Tan es así que se anunciaba que el ayuntamiento designaría "el lugar que considere más a propósito en la acequia sur" para que por cuenta de los interesados se construyera un "lavadero especial" en el que pudieran trabajarse "pieles, lana y demás materias destinadas a la industria". ${ }^{110}$

Todo el tercer capítulo se refería al "guarda encargado de la administración del ramo de regadíos”, en el que trataba de hacerse descansar la parte financiera del problema. En el cuarto y último capítulo del reglamento se agrupaban algunas "prevenciones generales", entre las que sobresalía la exigencia de formar un padrón general de las huertas que tuvieran derecho a recibir riego, hecho el cual "no se otorgarán nuevas concesiones de agua para regadío”. Se declaraban vigentes "las concesiones de agua acordadas para el servicio del alumbrado eléctrico de la ciudad y para el de los Talleres del Ferrocarril Central”, lo que recuerda que el agua ya no era sólo de los horticultores y que el gobierno se había erigido en autoridad capaz de mercedar y regular su uso. En su último artículo el reglamento reiteraba un deseo formula-

110 AGMA, H, c. 5, exp. 41. Sección Gráficos e Impresos. Reglamento de Regadíos del Municipio de la Capital, 1899. Se publicó en El Republicano (15 ene. 1899). 
do desde 1874, en el sentido de "suprimir el riego que reciben las huertas situadas en el centro de la ciudad", claro, en la medida en que los fondos públicos lo permitieran, porque había que indemnizar a sus dueños. Se argumentaba que ello era necesario para evitar "las molestias" que ocasionaban a los transeúntes los "bordos" o represas "que es preciso levantar en las calles", pero sobre todo para evitar el "estancamiento" del agua, lo cual "perjudica a la salubridad pública”.

Este reglamento fue objeto en 1904 de algunos cambios, muy pequeños pero reveladores de la forma en que evolucionaban las tensiones entre el huerto y la ciudad; entre el uso hortícola del suelo, que entraba en un proceso franco de decadencia, y los usos urbanos, que empezaban a ganar la partida. De hecho, se reiteraba la necesidad de retirar las huertas del centro de la ciudad, aunque se abandonaba la idea de indemnizar a sus dueños con recursos públicos; simplemente, se anunciaba que el ayuntamiento tenía la facultad de "suprimir el riego que reciben las huertas del interior de la ciudad" en tres casos: cuando los "estancamientos" producidos por los riegos o el encharcamiento mismo de las huertas representaran un "inconveniente para la salubridad pública"; cuando las huertas ocuparan el agua "para riegos de milpa o alfalfa", y cuando "un grupo de tres vecinos, cuando menos", se quejara "de que sus casas sufren con la humedad que les causa el riego de alguna huerta inmediata". Además, se establecía que "por ningún motivo se concederán riegos a las huertas que estén situadas dentro del perímetro de tres cuadras, a partir de la plaza principal, por todos los vientos”. Según el plano de Epstein, en 1855 todavía había huertas dentro de ese perímetro, sobre todo al oriente de la plaza. La medida bus- 
caba erradicarlas hasta la calle del Olivo, que en el ocaso del régimen porfiriano ya no marcaba el lugar donde la ciudad ceñía su romántico "cinturón de esmeralda". ${ }^{111}$

\section{LAS HUERTAS Y EL (DES)ORDEN URBANO}

Como dijo el regidor Evaristo Femat en 1895, los reglamentos de regadíos implicaban un esfuerzo para corregir el "desorden casi absoluto" que había en ese ramo, evitar los numerosos "abusos", atender las justas quejas de los regantes, facilitar el trabajo de los recaudadores y evitar los prejuicios que de todo ello se derivaban para las finanzas municipales. No puede menospreciarse este esfuerzo, pero debe reconocerse que su alcance fue limitado y que había problemas que no era posible resolver modificando el reglamento o volviéndolo más puntilloso. En general no se advierten medidas tendientes a mejorar técnicamente el sistema de riego, aumentar el caudal de agua disponible o abatir el desperdicio. Las demandas y quejas de los horticultores que se conservan en el archivo del cabildo proporcionan una buena radiografía de la forma en que funcionaba el sistema de riego y de la distancia que había entre la letra de los reglamentos y su aplicación, entre el afán de normar y los problemas derivados de la práctica cotidiana.

En los documentos se advierte cierta conciencia, que a veces alcanzaba niveles de alarma o histeria, sobre la "escasez" de agua o la "disminución" de la que aportaba el

111 AGMA, H, c. 294, exp. 59. "Reglamento de Regadíos del Municipio de la Capital”, 1904. Las modificaciones referidas al artículo 31 fueron aprobadas por el cabildo en sesión ordinaria del 12 de noviembre de 1904. 
manantial de Ojocaliente, lo que a lo largo de todo el periodo que estudiamos coexistió con un constante crecimiento de la demanda. Una causa muy importante de esta "escasez" tiene que ver con el hecho de que la oferta era rígida pero la demanda era elástica y no dejó de crecer a lo largo de la segunda mitad del siglo xIx. En 1863, cuando se formó el primer reglamento de regadíos, además de las huertas sólo se consideraban "los servicios públicos que semanalmente se hacen al jardín de San Marcos", los "tanques de [las] alfarerías" y las obras de la municipalidad. El reglamento de 1874 amplió en forma considerable el universo de entidades que tenían derecho al riego: al lado de las huertas y plantíos de viña, olivos, moreras, árboles frutales, hortaliza y verdura, incluyó las "alamedas, jardines públicos y paseos", los tanques de los alfareros y de las obras particulares y los sembradíos "de semillas y cereales". En el reglamento de 1899 se mencionaban específicamente "las fábricas de loza blanca, colorada y de ladrillo". El de 1904 establecía que los jardines, alamedas y paseos públicos serían regados de manera preferente no sólo los domingos, como era tradicional, sino también los "demás días que acuerden el presidente del ayuntamiento o el regidor del ramo”. Y hay que añadir que en el periodo 1863-1904 se formaron jardines en la plaza principal, la del Encino, Guadalupe y Cholula, sin contar la calzada Arellano, inaugurada en 1899, que era un paseo arbolado que se regaba con agua de la acequia de Texas. Todos estos espacios ejercieron en conjunto una presión creciente sobre un recurso que, hay que insistir, no tenía un carácter elástico. En el plano de la ciudad de 1900 formado por Medina Ugarte, se señalan nueve jardines públicos, 
incluido el de San Marcos, que seguía siendo el más grande e importante. ${ }^{112}$

La revisión del material documental no sugiere que hubiera un criterio bien definido y uniforme para tratar las nuevas demandas de agua. Unas veces se obsequiaban después de verificar que la huerta del solicitante reuniera determinadas características y otras se negaban con el argumento genérico y siempre a la mano de que el agua del manantial no era suficiente, sin importar lo bien fundado de la solicitud. Sucedía también que se dictaminaba que no había agua para atender a todas las huertas que tenían derecho, a pesar de lo cual se otorgaban nuevas mercedes; en esas ocasiones se llegó a decir, en forma curiosa o propia de un pragmatismo resignado, que no podía negarse a unos lo que a otros había sido concedido, o que en realidad no importaba que el problema de la escasez de agua se agudizara un poco con dotaciones adicionales. Pero también se empleaba en ocasiones el razonamiento contrario, es decir, se negaba una merced nueva por la sencilla razón de que a otros se les había negado antes, sin considerar su grado de fundamento ni haber inspeccionado la huerta del solicitante. Un argumento que se usaba de manera recurrente era el de impulsar el cultivo de la vid o de la morera, lo que acarrearía beneficios no sólo al interesado, sino al desarrollo de esas industrias, cuyo fomento había tomado a su cargo el gobierno. En ocasiones se nota que influía mucho la personalidad del solicitante, pues a un horticultor pobre y desconocido se negaba lo que se concedía sin demasia-

112 "Plano de la ciudad de Aguascalientes formado por el Ingeniero Tomás Medina Ugarte por disposición del Gobierno del Estado, año de 1900", Mapoteca del AHEA. Hay una excelente recreación de este plano en Martínez Delgado, Cambio y proyecto urbano, p. 198. 
dos trámites a un personaje conocido y posiblemente influyente, por ejemplo un funcionario del gobierno del estado o un eclesiástico. El reglamento de regadíos se usaba como arma de dos filos, unas veces como fundamento legal de una resolución negativa y otras para conceder lo solicitado.

En realidad, la gestión del riego fue uno de los terrenos en los que se dio ese desfase entre los gobiernos liberales, empeñados en transformar al país, y un pueblo marcado por los malos hábitos del pasado colonial, que se negaba pertinazmente a entrar en el camino de la modernidad. Como ha mostrado Delgado, en Aguascalientes los gobernantes veían con "profundo desencanto" a la sociedad y la juzgaban incapaz de salir de su estado de "atraso, incivilidad e ignorancia". ${ }^{113}$ Siguiendo a Guerra, podemos decir que los miembros de la clase dirigente se veían a sí mismos como una "élite revolucionaria a punto de transformar profundamente una sociedad arcaica", impregnada hasta la médula de los "valores antiguos" y por supuesto "reacia al cambio". El regidor Femat sería un miembro de esa "minoría ilustrada" convencida de que tenía la "misión histórica" de convertir a la vieja sociedad en un pueblo "moderno", a los huerteros en ciudadanos responsables y a los jueces de aguas en funcionarios incorruptibles. ${ }^{114}$

Ya viejo, Arturo Pani (1879-1962) recordaba o creía recordar que hacia 1890, Aguascalientes era una ciudad amable, tranquila y encantadora por sus huertas, "que un clima benigno y agua en abundancia hacían hermosas y productivas"; un pueblo en el que había "bellos jardines", "frondo-

113 Delgado Aguilar, Jefaturas políticas, p. 161.

114 Guerra, México: del Antiguo Régimen a la Revolución, t. I, p. 182. 
sos árboles”, calles limpias, "anchas y rectas, cuidadosamente empedradas", en cuyo centro había una zanja que constituía "el único sistema de drenaje que existe"; todo contribuía a crear "un ambiente de armónica quietud en el que nada disuena", ni siquiera los pregones de los vendedores ambulantes de "canutos de limón", charamuscas y gorditas de cuajada. ${ }^{115}$ Pero en realidad, como ha demostrado Delgado, en la época de la República Restaurada, e incluso a fines del porfiriato, la ciudad estaba muy lejos de esa imagen idealizada. Las calles, supuestamente limpias y bien trazadas, eran el escenario en el que cotidianamente se enfrentaba el gobierno, convencido de su misión civilizadora, implacable en su deseo de desterrar las condiciones de suciedad, insalubridad y desorden imperantes, con los limosneros que importunaban con sus lamentos, los artesanos que ocupaban las banquetas para realizar sus actividades, los aguadores cuyos burros defecaban sin escrúpulo, los vagos que infestaban las plazas públicas y los atrios de las iglesias y los borrachos que orinaban en cualquier esquina o directamente en las acequias. ${ }^{116}$

Es curioso y significativo que atenido a sus recuerdos de infancia Pani diga que las zanjas que corrían por en medio de las calles constituían un "sistema de drenaje", porque ese "sistema" no existía y las zanjas que vagamente recuerda eran en realidad las acequias que conducían el agua con que se regaban las huertas, agua que en teoría era limpia, incolora e inodora. Lo cierto es que las acequias estaban habitualmente sucias y obstruidas por la basura, lo que nos ayuda a enten-

115 Pani, Ayer, pp. 181-182.

116 Delgado Aguilar, Jefaturas políticas, p. 213. 
der los traicioneros recuerdos de Pani. ${ }^{117}$ No por nada, el artículo 15 del reglamento de regadíos de 1863 prohibía tirar basura en las acequias, pues ello iba "en contra de la policía" y provocaba que el agua quedara sofocada en los caños, lo que era origen de "otro mal". Esta prohibición fue reitera$\mathrm{da}$ en los reglamentos posteriores, lo que sugiere que nunca se pudo extirpar la costumbre de usar las acequias como basureros. En más de una ocasión se denunció la corrupción que emanaba del "inmundo caño o acequia" que corría por la calle del Apostolado, apenas a dos cuadras de su casa. ${ }^{118}$ En diciembre de 1886, cuando Pani tenía siete años y era hechizado por la limpieza y buen empedrado de las calles, el cabildo acordaba reparar las acequias "que pasan por las principales calles de la población”, porque estaban "llenas de hoyos y desigualdades donde se estanca el agua y se aglomera la basura". ${ }^{119}$ Un poco antes, en febrero de 1881, cuando Pani era todavía un bebé de brazos, su abuelo Manuel Arteaga y otros vecinos de la primera calle de San Diego (gente distinguida, como José Bolado, Felipe Nieto y Rafael Arellano) se quejaban porque "el agua de los regadíos" que corría por ahí estaba causando "grandísimos perjuicios" a sus fincas; según explicaban, hacía poco se había modificado la acequia, que ya no corría por el centro de la calle, sino

117 El carácter inexacto o francamente fantasioso de los recuerdos de infancia de Pani remite a "las trampas de la memoria", la capacidad que tienen las personas para "recordar experiencias que no han vivido" y "la construcción colectiva del recuerdo", incluso recuerdos falsos, problemas todos ellos abordados por la psicología. Véase Mazzoni, ¿Se puede creer a un testigo?

118 “Acequias insalubres”, La Libertad de México (3 dic. 1865).

119 AGMA, H, c. 133, exp. 44. 
pegada a la acera, lo que provocaba grandes humedades en los muros y determinaba que en poco tiempo sus casas quedarían "inhabitables". Explicaban que por su ubicación en el centro de la ciudad esa calle era "una de las más transitadas, y es notoria la molestia que sufren todas las personas, y muy especialmente el bello sexo al pasar las acequias". Añadían que no tenía caso que una acequia discurriera por ahí porque en esa calle no había "ninguna huerta para regar", y si la hubiere "por razones de conveniencia debía quitarse". ${ }^{120}$

Esta sugestiva confusión entre un drenaje inexistente y acequias por las que en teoría corría agua limpia y cantarina, dice Martínez Delgado, es frecuente en la historiografía urbana, nutrida por "cronistas nostálgicos" y libros de viajeros, en los que abundan "imágenes idealizadas de ciudades bellas, alegres, limpias y modernas"; medidas con "parámetros contemporáneos de limpieza", sentencia este autor, Aguascalientes y todas las demás ciudades mexicanas eran sucias y tenían muchos "problemas de salubridad", a los que se añadieron, en la época porfiriana, los que provocó la violenta industrialización. ${ }^{121}$ No existía como tal un "sistema de drenaje”, ni siquiera el muy sencillo que creía recordar Pani, consistente en zanjas a cielo abierto que discurrían por mitad de las calles, aunque curiosamente Martínez Delgado, que nos previene con buenas razones contra las mentiras e idealizaciones de la literatura de viajeros, le da crédito a Pani y supone que esas zanjas existían y que los "desechos" que por ellas corrían iban a dar a "los arroyos". ${ }^{122}$ En realidad, en la

120 AGMA, $H$, c. 118, exp. 29. "Solicitud de cambio de curso de acequia por perjudicar fincas", $1^{\circ}$ de febrero de 1881.

${ }_{121}$ Martínez Delgado, Cambio y proyecto urbano, pp. 98-99.

${ }^{122}$ Martínez Delgado, Cambio y proyecto urbano, p. 165. 
época recreada por Pani, las autoridades apenas empezaban a tomar conciencia de estos problemas y consideraban alternativas para enfrentarlos. A principios de 1886, luego de reconocer que las acequias que por todos lados atravesaban la ciudad estaban sucias y desniveladas y eran por lo mismo un foco de corrupción, el cabildo de Aguascalientes hacía suya una iniciativa del jefe político del partido de la capital encaminada a adoptar medidas de higiene "muy necesarias y convenientes a la categoría de la población”; concretamente le dirigía a la legislatura una "respetuosa súplica” para que dispusiera que se construyeran "pozos absorbentes o resumideros” en todas las casas de la ciudad donde no los había (la mayoría), pues sólo así dejarían de arrojarse "las aguas sucias en la calle, como se observa”. También pedía que se construyeran "comunes" (retretes) y que se reglamentaran las casas de vecindad y los mesones, asegurando que reunieran condiciones de "limpieza, comodidad y seguridad". ${ }^{123}$

\section{“ENGULLIDAS POR EL PROGRESO"}

En el siglo xviI el barrio de Triana y el de Texas en el xviII no fueron en sus orígenes comunidades humanas más o menos numerosas y organizadas, sometidas al control administrativo de las autoridades de la villa de Aguascalientes, sino espacios cultivados, eslabones de ese "cinturón hortícola” que aseguraba el abasto de frutas y verduras y abatía los costos asociados a la transportación. Ello fue facilitado por

123 AGMA, H, c. 133, exp. 44. "Propuesta del jefe político Isaac Ruiz de la Peña para mejorar las condiciones higiénicas de la ciudad”, 17 de febrero de 1886. 
el emplazamiento de la villa en el corazón de un extenso valle cultivable y regado por las aguas del manantial de Ojocaliente, el cual, pese a todas las dificultades y abusos, fue capaz de dar agua a un número siempre creciente de huertas. Lo mismo que en muchos asentamientos europeos de la temprana edad moderna, la villa de Aguascalientes señoreaba "los campos de su entorno", ${ }^{124}$ lo que a su vez remite a la enorme influencia que tuvieron las huertas en la definición del proceso urbano, pues sólo con el paso del tiempo y debido al crecimiento de la población estos barrios adquirieron el aspecto de verdaderos caseríos. De la misma manera que en Orizaba, las huertas no pueden conceptuarse como el binterland de la ciudad, sino como un "espacio intrínseco del paisaje urbano", lo que se evidenciaba en el hecho de que las calles tenían nombre y "formaban manzanas bien delimitadas y sumamente regulares" ${ }^{125}$ En su conjunto, las huertas y el sistema de acequias determinaron lo que una autora, refiriéndose a la Tudela andalusí, llama "la ordenación del entorno". 126

La horticultura se consideraba una actividad de interés público, que acarreaba ventajas estéticas, funcionales e incluso higiénicas, por lo que se tomaron un sinfín de medidas destinadas a alentarla y regularla. En su momento de máximo esplendor (1883), había 459 huertas que se regaban con agua de Ojocaliente y otras 150 que contaban con pozos o norias propios; en total unas 600 huertas, que asombraron a cronistas como Correa, quien recorría toda la ciudad sin encontrar un barrio en el que no hubiera alguna, "escondiendo en su

124 Braudel, Civilización, p. 93.

125 Ribera Carbó, Herencia colonial y modernidad burguesa, p. 120.

126 Hernández Charro, “Agua y poblamiento”, p. 316. 
interior paisajes de jardín”. ${ }^{127}$ Sembradas en su mayor parte de árboles frutales y algo de viña, ocupaban una extensión de 200 ha, casi $40 \%$ de la superficie que tenía la ciudad en 1855, cuando Isidoro Epstein formó su "Plano de las huertas".

A fines del siglo XIX, a partir de la reconstrucción de la acequia de Ojocaliente, la ecuación entre horticultura e higiene pública se alteró, iniciándose lo que algunos autores caracterizan como "tránsito de lo rural a lo urbano". ${ }^{128}$ Si antes se consideraban un factor positivo, sobre todo porque eran el medio de vida de muchas familias y abastecían a la población de frutas y hortalizas, ahora se empezó a reparar en sus inconvenientes. No deja de ser paradójico que eso sucediera precisamente entonces, cuando la reconstrucción de la acequia de Ojocaliente (1899) aumentó en forma considerable la cantidad de agua de que se dispuso, lo que en teoría beneficiaba directamente a la horticultura. Sin embargo, lo que dio inicio fue una ofensiva muy clara contra las huertas, pues por razones de higiene el reglamento de regadíos de 1904 prohibió regar las que estaban "situadas dentro del perímetro de tres cuadras, a partir de la plaza principal, por todos los vientos”. Además se previó que cuando el agua se estancara en su interior serían consideradas un "peligro para la salubridad pública”, lo que justificaría la suspensión del servicio de riego, es decir, su destrucción. ${ }^{129}$

Una clave fundamental del quiebre histórico del papel que desempeñaban las huertas en la vida de la ciudad está en la evolución demográfica: 30000 habitantes en 1895, 35000 en

127 Correa, Un viaje a Termápolis, p. 127.

128 Castillo Palma, Cuando la ciudad llegó a mi puerta, p. 17.

129 Artículos 31 y 32 del reglamento de regadíos de 1904. 
1900 y 45000 en 1910, lo que significa que en un lapso de sólo 15 años la población del lugar creció $50 \%$. ${ }^{130}$ Pero fue más importante el crecimiento de la presión ejercida sobre el agua, un recurso crucial en el contexto de la emergencia de nuevos hábitos de higiene pública y privada. La fecha exacta de ese quiebre podría situarse en el 11 de abril de 1899, momento en el que, ya reparada la acequia y aumentado de manera sustancial el caudal de agua disponible, el cabildo publicó las "condiciones bajo las cuales se conceden mercedes de agua a domicilio en esta capital". ${ }^{131}$ Hasta marzo de1904 se habían atendido 368 solicitudes, lo cual, considerando que a cada usuario se le daban 800 litros por día, importaba $294.4 \mathrm{~m}^{3}$, el equivalente de 3.15 naranjas. ${ }^{132} \mathrm{Si}$ recordamos que en 1856 el cabildo se había reservado apenas una naranja para el servicio de las fuentes públicas de la ciudad y que no se daba servicio de agua potable a las casas, advertiremos la magnitud del cambio. La cantidad de agua disponible creció en forma sustancial, pues a la que se mercedó a los particulares habría que añadir la que abastecía un número creciente de fuentes públicas (cinco en 1861 y más de 30 en 1900), pero los beneficiarios fueron los particulares, mientras casi al mismo tiempo se emprendía una prolongada batalla contra las huertas, residuo de un pasado al que se daba la espalda y contra el que se combatía en forma abierta. ${ }^{133}$

130 Estadísticas, t. I, cuadro 1.51: "Población total de la ciudad de Aguascalientes, Ags. Años seleccionados de 1794 a 2005”.

131 AGMA, H, c. 6, exp. 24, sección Gráficos e Impresos.

132 AGMA, $H$, c. 250, exp. 13. "Solicitudes de mercedes de agua a domicilio, 1899-1904."

133 Martínez Delgado, Cambio y proyecto urbano, pp. 153-156, reseña "la primera instalación moderna de agua potable en red". 
Acogiéndose al reglamento de regadíos de 1904, Alberto E. Chávez argumentó que había invertido 10000 pesos en la construcción de tres casas nuevas, pero que estaba muy preocupado porque lindaban con la huerta de la señora Refugio Jiménez, lo cual implicaba que la humedad las volvería "inhabitables". En forma bastante clara, el quejoso sugería que había un conflicto irreductible entre la horticultura, esa actividad propia del pasado, y "el ensanche asombroso de la ciudad", la modernidad, que había llegado de la mano de un "magnífico templo católico" (San Antonio), "un excelente establecimiento de instrucción primaria” (el Liceo de Niñas) y las líneas del tranvía urbano. El cabildo, institución "encargada de velar por los intereses sociales", debía suprimir las huertas e impulsar la construcción de nuevas casas. ${ }^{134}$ Como ha señalado Delgado, a la vuelta del siglo el gobierno estableció "una relación directa entre higiene urbana y abasto domiciliario" de agua, lo que modificó la secular interdependencia que había entre el cultivo de las huertas y el interés público; en el lugar de la horticultura fueron puestos "los usos domésticos del agua". ${ }^{135}$

Debido al gran arraigo que tenían en la vida de la localidad, las huertas no fueron liquidadas en el corto plazo por las restricciones que se impusieron en el acceso al riego y la construcción de nuevas casas, escuelas e iglesias. En un trabajo publicado hace casi 30 años afirmé que a fines del porfiriato las huertas fueron abandonadas y que murieron "por eutanasia", ${ }^{136}$ tesis que ha sido rebatida por Delgado,

134 AGMA, H, c. 329, exp. 44.

135 Delgado Aguilar, "Obra pública, cambio urbano y protesta social”, p. 187.

136 Gómez Serrano, Aguascalientes en la historia, t. III, p. 136. 
quien ha demostrado que en realidad el proceso fue más lento y gradual, pues tomó toda la primera mitad del siglo xx. "Poco a poco - sostiene este autor- el interés público dejó de identificarse con la horticultura y comenzó a relacionarse con el crecimiento de la ciudad y con una idea de higiene urbana que rechazaba la presencia de huertas y acequias tanto en el centro de la capital como en las nuevas colonias." A partir de 1899, añade, las mejoras hechas en el sistema de abasto "estuvieron impulsadas por la necesidad de aumentar el caudal de agua para el consumo de los habitantes y no para fines de irrigación". ${ }^{137}$

En los primeros años del siglo xx se construyeron los gigantescos Talleres Generales del Ferrocarril Central y se establecieron diversas factorías en el corredor industrial que se formó junto a las vías del tren, de manera señalada la fábrica de harinas y almidones La Perla y la Fundición de Fierro y Bronce, todo lo cual determinó la apresurada urbanización de los terrenos que había entre la estación del ferrocarril y la calle del Olivo, que a mediados del siglo XIx marcaba todavía el límite del perímetro urbanizado. Todo el barrio de Texas, formado a fines del siglo XviII y característico por sus huertas, fue afectado directamente por este embate y de hecho desapareció como tal de la geografía urbana. En un padrón formado en 1914 fueron registradas sólo 286 huertas, 169 correspondientes al "circuito" de Texas y 117 al de Triana. Poco después, en junio de 1920, se formó un nuevo "padrón general" de las huertas que conservaban derecho a riego, según el cual había 173 que dependían de la acequia de Texas

137 Delgado Aguilar, "Obra pública, cambio urbano y protesta social”, pp. 187-188. 
y otras 73 de la de Triana, un total de 246 huertas con riego. ${ }^{138}$ Esta cantidad equivale apenas a un poco más de la mitad de las huertas que se regaban en 1883 , lo que quiere decir que la tendencia secular a la expansión del cinturón hortícola que rodeaba la ciudad se había interrumpido y comenzaba un periodo de retracción. Una comparación superficial entre el plano de la ciudad que formó Epstein (1855) y los que levantaron Medina Ugarte (1900) y Villaseñor (1918) muestra la medida y la velocidad con que la vieja "ciudad de las flores y los frutos” había sido vencida por una nueva urbe característica por sus fábricas, sus bancos, sus hoteles, sus jardines públicos y sus colonias. ${ }^{139}$ En el plano de Villaseñor el estanque de la Alameda (ahora llamado de La Cruz) aparece mutilado y la colonia Buenavista está trazada sobre las huertas de lo que había sido el barrio de Texas; las nuevas colonias Héroes y del Trabajo, por su parte, se proyectan al oriente de los Talleres del Ferrocarril, en terrenos de la antigua hacienda de Ojocaliente que todavía en 1890 eran ocupados por trigales y huertas arboladas, según puede verse en el "Plano del suelo fósil de la ciudad”. ${ }^{140}$ Es muy sugestivo el hecho de

138 AGMA, H, c. 402, exp. 17. "Huertas de los circuitos de Texas y Triana”, 1914; AGMA, H, c. 495, exp. 3. "Padrón general de las huertas que tienen derecho al riego", 12 de junio de 1920. El barrio de Texas había desaparecido como tal, pero se conservaba la acequia, con la que se regaban huertas en el barrio de San Marcos, la calle de Zaragoza (antigua del Olivo), la avenida Madero y otros puntos.

139 "Plano de la ciudad de Aguascalientes formado por el Ingeniero Tomás Medina Ugarte por disposición del Gobierno del Estado, año de 1900" y "Plano de la ciudad de Aguascalientes levantado en el año 1918 por Arnulfo Villaseñor” (editado por R. Loreto y Cía.), ambos en la mapoteca del AHEA.

140 Publicado por DíAz de LEón, “Apuntes para el estudio de la higiene”, entre las páginas 184-185. 
que ni Medina Ugarte ni Villaseñor señalen la existencia de huertas en la ciudad, que a mediados del siglo xIx (no hacía mucho tiempo, en realidad) eran su característica más importante. Aunque no habían desaparecido por decreto, esta omisión es reveladora de que en el imaginario oficial ya no eran ni debían ser el sello distintivo de una ciudad que se quería moderna, bien trazada y dotada de servicios. La verdad es que entre 1890 y 1914, en menos de 25 años, la mancha urbana creció como no lo había hecho en los tres siglos anteriores y las huertas, aunque hasta cierto punto se mantuvieron durante algunas décadas como "algo típico de Termápolis", dejaron de ser ese "cinturón de esmeralda" que rodeaba su talle "como una caricia”, según la caracterización hecha por Correa para la década de 1870.

A ello aludía en 1914 el regidor José Arteaga cuando reconocía que "la construcción de casas y la apertura de amplias avenidas" en "la parte noroeste de la ciudad" (precisamente el antiguo barrio de Texas) habían implicado la desaparición o la reducción de la superficie de un "considerable número de huertas", lo que aconsejaba que se hicieran ajustes en el sistema de riego. ${ }^{141}$ Ese mismo año se abrió la avenida Convención (después Madero), que partió por la mitad una enorme huerta que había entre la plazuela San Juan de Dios y la calle Independencia, lo que elevó en forma sustancial el valor del suelo y determinó su urbanización; como se apunta en un libro de recuerdos, la apertura de esa "calle recta y amplia", que supuestamente iba a permitir que desde las bancas de la plaza se pudiera ver "el paso de los trenes", fue facilitada por el hecho de que en toda el área afectada por su trazo había

${ }^{141}$ AGMA, $H$, c. 402, exp. 17. 
“multitud de huertas". ${ }^{142}$ Con celeridad desconocida se arrasaron casas y jacalones y se expropiaron terrenos y huertas “por causa de utilidad pública”, lo que permitió abrir a la circulación la nueva calle antes de que llegaran a la ciudad los delegados de la Soberana Convención Revolucionaria. Es sintomático que en la historiografía reciente se pueda leer que esa obra, a pesar de que fue "un golpe más a la tradición hortelana de la localidad", no implicó demasiados perjuicios, “ya que no se demolieron edificios de importancia”. ${ }^{143}$

En 1921 los vecinos de la calle Los Patos dijeron que los riegos que se daban a la huerta de un vecino perjudican "nuestros pequeños intereses", o sea, sus casas habitación, las cuales "merecen un lugar preferente a las huertas”, pues pagaban más impuestos y la calle en sí estaba más "urbanizada”, lo que por lo visto aconsejaba eliminar las últimas huertas que quedaban en ella. En 1934 un funcionario federal dijo que el "aumento de población” se había traducido en la decadencia de la horticultura, lo que era visible en la forma en que se distribuía el agua, que ya no anegaba las huertas sino que era dedicada a satisfacer necesidades "domésticas y públicas”. En la década de 1940 los vecinos de diversos barrios eran multados porque usaban sus tomas de agua para regar huertas y el cabildo comenzó a suspender de forma sistemática todas las mercedes que se usaban con estos propósitos. Se dio el caso de que los vecinos de alguna calle o colonia denunciaran que carecían de líquido en sus casas debido "a las numerosas mercedes de agua dadas a huertas

142 Martínez López, El Aguascalientes que yo conocí, p. 93.

143 Ramírez Hurtado, "La apertura de la Avenida de la Convención”, pp. 109, 111. 
por el rumbo de San Marcos", argumento que llevaba implícita una petición de principio en el sentido de que éstas no debían regarse. Las acequias dejaron de conceptuarse como las venas que mantenían viva una actividad típica de la ciudad y fueron señaladas como "verdaderas amenazas para la higiene pública y la moral”. En resumen, dice Delgado, la ciudad que crecía convirtió las huertas y acequias "en factores que perjudicaban la higiene". ${ }^{144}$

Se disponía cada vez de más agua potable que se dedicaba por completo a los usos domésticos. Los horticultores se vieron en la necesidad de recurrir a las aguas negras, que abundaban debido a la expansión del drenaje. En un principio, el control de estas aguas estuvo en manos del cabildo, que autorizaba su aprovechamiento a cambio del pago de "las tarifas correspondientes". En 1946 el Congreso del estado reglamentó su uso y distribución. ${ }^{145}$ Por la misma época, en los alrededores de San Luis Potosí se usaban para riego "las aguas de desecho municipal e industrial". ${ }^{146} \mathrm{La}$ verdad es que "las huertas de la ciudad desaparecían paulatinamente bajo el pavimento y las construcciones". ${ }^{147}$ Éste es uno de esos procesos de largo aliento que no fue de ninguna manera interrumpido por la revolución de 1910 y el nuevo marco normativo. No deja de ser una ironía de la historia que las cloacas fueran la última trinchera que defendieron los dueños de las huertas de la ciudad, cuyos ancestros pagaron en 1644 una

144 Delgado Aguilar, "Obra pública, cambio urbano y protesta social", pp. 188-200.

145 Delgado Aguilar, "Obra pública, cambio urbano y protesta social”, pp. 192-193.

146 Cirelli, “Aguas negras,”, p. 213.

147 SAlmerón, Intermediarios del progreso, p. 85. 
composición que les aseguraba el uso preferente y a perpetuidad de las aguas del manantial de Ojocaliente "para el servicio de sus casas y familias, riego de sus tierras, viñas y chilares”.

En 1933 los horticultores formaron un sindicato con el propósito de mejorar el cultivo de las huertas, que se hallaba en decadencia debido a la "falta oportuna de riegos". Como primera medida solicitaron la "confirmación” de los derechos que tenían al uso de las aguas de Ojocaliente, que según argumentaron usaban "desde tiempo inmemorial”, lo cual era cierto, aunque por lo visto no conocían el título de composición de 1644, que constituía la piedra angular de sus derechos. La Liga de Horticultores le ganó algunas batallas al cabildo, que por su lado trató de demostrar que tenía la titularidad de esos derechos. Incluso, el gobierno federal reconoció a la Liga y le permitió administrar el agua que se empleaba para regar huertas, un "hecho inédito", como dice Delgado, aunque a la postre meramente anecdótico. Ello quedó claro en diciembre de 1941, cuando se tomó la decisión irrevocable de desecar el estanque de la Cruz, argumentando que era un "foco insalubre"; en su lugar debía promoverse un fraccionamiento "apropiado para la construcción de casas saludables y rodeadas de jardines y arboleda”, que dispusiera de agua potable "en abundancia” y que contara con un "drenaje dual” para separar las aguas negras de las pluviales. Hubo todavía algunas escaramuzas que consumieron cierto tiempo, hasta que en marzo de 1946 la legislatura local publicó un decreto que autorizaba al cabildo a vender "los terrenos de su propiedad ocupados por el llamado Estanque Viejo o de La Cruz", debiéndose usar dichos terrenos "precisamente a ser urbanizados mediante fraccionamiento", lo cual se hizo, aunque en forma salvaje, como en el resto de la 
ciudad, sin jardines ni arboledas, mucho menos el cacareado "drenaje dual". ${ }^{148}$ La clausura del estanque fue "un golpe mortal" para la horticultura y provocó "la indignación popular y la protesta generalizada", que de nada valieron; la perforación de un pozo profundo y la construcción de un tanque elevado de agua de gran capacidad no resolvieron el problema del abasto, pues pronto "volvió a haber escasez de agua potable" y los habitantes del nuevo fraccionamiento no tenían la necesaria "ni para lavar la ropa" ${ }^{149}$ Es revelador que el contratista de las obras hablara de la necesidad "primordial" de abrir nuevas calles y de modificar la traza de ese y otros barrios periféricos, que estaban mal comunicados con el centro de la ciudad debido a "la amplitud de las manzanas que forman la antigua planificación, actualmente fuera de época y merecedora de una completa reforma". ${ }^{150}$ Las huertas, pues, pertenecían a un pasado que se juzgaba superado.

Es necesario insistir en el carácter crucial de la variable demográfica. La ciudad había llegado a albergar 45000 habitantes en 1910, pero el crecimiento se ralentizó durante la década revolucionaria; aunque se volvió imparable una vez que se pacificó el país: 62000 habitantes en 1930, 82000 en 1940, 93000 ; en 1950 y 126000 en $1960 .{ }^{151}$ Gracias a su crecida población, su industria y sus servicios, Aguascalientes se convirtió en una ciudad de tipo medio que "exigió la amplia-

148 Delgado Aguilar, "Obra pública, cambio urbano y protesta social”, pp. 201-210; AHEA, PL, c. 262, exp. 22.

149 Madrid Alanís, Manantiales: vida y desarrollo, siglos XVI-XX, p. 146.

150 "Fraccionarán la zona del estanque de La Cruz", El Sol del Centro (7 ago. 1946).

151 Estadísticas, t. I, cuadro 1.51: "Población total de la ciudad de Aguascalientes, Ags. Años seleccionados de 1794 a 2005”. 
ción de la infraestructura hidráulica” y la perforación de un número desmedido de pozos profundos, sin que la "extracción incontrolada” de agua fuera capaz de saciar su sed. ${ }^{152}$

En este contexto se entiende mejor la inutilidad de todas las gestiones orientadas a frenar o revertir el proceso de decadencia de la horticultura, como las que hizo en 1952 el gobernador Edmundo Games Orozco, dueño de una de las últimas huertas que hubo en la ciudad. Ese "sitio delicioso", depositario de las leyendas románticas asociadas a la horticultura, era la sede de una verbena que se organizaba cada año en el marco de la feria de San Marcos, a la que eran invitados poetas, periodistas, pintores y otros personajes procedentes de la ciudad de México. ${ }^{153}$ Transido de nostalgia, Games afirmaba que las huertas habían sido "uno de los factores más sólidos" de la economía de la ciudad casi desde la época de su fundación, pero que el crecimiento de ésta y el aumento de su población habían determinado su abandono, "hasta el grado de que paulatinamente fueron desapareciendo la mayor parte de esas huertas por falta de riegos oportunos". Argumentando que las que todavía quedaban sobrevivían con un riego "exiguo e insuficiente", Games le pedía a la Secretaría de Recursos Hidráulicos, que era la instancia del gobierno federal que ahora arbitraba los asuntos locales de aguas, que autorizara que los horticultores pudieran usar para sus riegos las aguas de cierto pozo. ${ }^{154}$ Vista en perspectiva, ésta fue apenas una pequeña escaramuza que

${ }^{152}$ Madrid Alanís, Manantiales: vida y desarrollo, siglos XVI-XX, p. 184. 153 Castillo, "Hacia la feria de San Marcos”, pp. 163-171.

154 AHEA, SGG, expediente sin clasificación. "El gobernador Edmundo Games Orozco escribe al ingeniero Manuel Anaya, jefe de ingeniería sanitaria de la Secretaría de Recursos Hidráulicos”, 12 de junio de 1952. 
sólo prolongó la agonía de las huertas y aplazó por un tiempo la ejecución de una sentencia ineluctable.

La verdadera respuesta a la solicitud de Games Orozco llegó unos años después, cuando el gobernador Luis Ortega Douglas (1956-1962) obtuvo de la Secretaría de Recursos Hidráulicos un "valioso donativo" de 500000 pesos para entubar el arroyo de Los Caleros y construir sobre su cauce un gran eje que atravesara la ciudad en sentido OrientePoniente, al que se impuso el nombre del presidente López Mateos, quien se había revelado como "domador" de la insurgencia ferrocarrilera y "campeón del moderno sistema escolar público". ${ }^{155}$ La horticultura conservó sus últimos reductos sobre la calle del Acueducto y la de los Placeres, en el barrio La Salud, pero la nueva avenida fue una inmensa loza de concreto que la aplastó de manera definitiva e irreversible. Directamente afectada por el trazo de la nueva avenida, la huerta Games, la de las verbenas de abril, fue partida en dos y su mitad norte se convirtió en parque urbano y mercado. Como dijo alguien que atestiguó esos hechos, fue "engullida por el progreso". ${ }^{156}$

\section{SIGLAS Y REFERENCIAS}

AGMA, $A C D$ Archivo General Municipal de Aguascalientes, fondo Actas de Cabildo Digitalizadas, Aguascalientes, Aguascalientes.

AGMA, $H$ Archivo General Municipal de Aguascalientes, fondo Histórico, Aguascalientes, Aguascalientes.

155 Ortega Douglas, Segundo Informe de Gobierno, pp. 32-33, 87 y 90; Ortega Douglas, Tercer Informe de Gobierno, p. 112; Salmerón, Intermediarios del progreso, p. 87.

${ }^{156}$ Martínez López, El Aguascalientes que yo conocí, p. 131. 
AGN, IC Archivo General de la Nación, fondo Industria y Comercio, México, D.F.

AGN, $P$ Archivo General de la Nación, fondo Padrones, México, D.F.

AHEA, $E$ Archivo Histórico del Estado de Aguascalientes, fondos Especiales, Aguascalientes, Aguascalientes.

AHEA, $P N \quad$ Archivo Histórico del Estado de Aguascalientes, fondo Protocolos Notariales, Aguascalientes, Aguascalientes.

AHEA, PL Archivo Histórico del Estado de Aguascalientes, fondo Poder Legislativo, Aguascalientes, Aguascalientes.

AHEA, SGG Archivo Histórico del Estado de Aguascalientes, fondo Secretaría General de Gobierno, Aguascalientes, Aguascalientes.

AHMG Archivo Histórico Municipal de Guadalajara, Guadalajara, Jalisco.

BSHGEA Boletin de la Sociedad de Historia, Geografía y Estadística de Aguascalientes, Aguascalientes, Aguascalientes.

MOB Mapoteca Manuel Orozco y Berra, Antiguo Arzobispado de Tacubaya, México, D. F.

Aвoites Aguilar, Luis

El agua de la nación. Una historia política de México (18881946), México, Centro de Investigaciones y Estudios Superiores en Antropología Social, 1998.

Acevedo Escobedo, Antonio (selección y prólogo)

Letras sobre Aguascalientes, Aguascalientes, Gobierno del Estado, 1976.

AMAdor, Elías

Bosquejo histórico de Zacatecas, Aguascalientes, Talleres Tipográficos de Pedroza, 1943.

Ávila, Joaquín de, Francisco Romo de Vivar, Manuel Alejandro Calera y Francisco Semería

"Noticias estadísticas del Departamento de Aguascalientes correspondientes al año de 1837. Primer cuadro estadístico 
del Departamento de Aguascalientes”, en Boletín de la Sociedad Mexicana de Geografía y Estadística, 1: 8 y 9 (ene. y feb. 1850), pp. 171-196.

Bakewell, Peter J.

Minería y sociedad en el México colonial. Zacatecas (15461700), México, Fondo de Cultura Económica, 1976.

Berumen Félix, Claudia

“Administración de aguas para riego en Jerez, 1786-1861", tesis de licenciatura, Zacatecas, Universidad Autónoma de Zacatecas, 2000.

Braudel, Fernand

Civilización material, economía y capitalismo. Siglos XVXVIII, t. 1, Las estructuras de lo cotidiano: lo posible y lo imposible, Madrid, Alianza Editorial, 1984.

Carabarín Gracia, Alberto

Agua y confort en la vida de la antigua Puebla, Puebla, Instituto de Ciencias Sociales y Humanidades, Benemérita Universidad Autónoma de Puebla, 2000.

Castillo, Guillermo

"Hacia la feria de San Marcos", en Acevedo Escobedo, 2003, pp. 163-171.

Castillo Palma, Norma Angélica

Cuando la ciudad llegó a mi puerta: una perspectiva bistórica de los pueblos lacustres, la explosión demográfica y la crisis del agua en Iztapalapa, México, Universidad Autónoma Metropolitana-Iztapalapa, 2012.

Chevalier, François

La formación de los latifundios en México. Tierra y sociedad en los siglos XVI y XVII, México, Fondo de Cultura Económica, 1976. 
Cirelli, Claudia

"Aguas negras, agricultura periurbana y organización de regantes", en Palerm Viqueira y Martínez Saldaña, 2000, pp. 211-252.

Correa, Eduardo

Un viaje a Termápolis. Óleos antiguos, México, Ediciones Botas, 1937.

Cosío Villegas, Daniel (dir.)

Historia moderna de México; el Porfiriato. Vida Económica, México, Hermes, 1974.

Delgado Aguilar, Francisco Javier

Jefaturas políticas. Dinámica política y control social en Aguascalientes, 1876-1911, Aguascalientes, Universidad Autónoma de Aguascalientes, 1998.

"Obra pública, cambio urbano y protesta social en la primera mitad del siglo xx. El abasto de agua en la ciudad de Aguascalientes", tesis de doctorado en historia, México, El Colegio de México, 2011.

Díaz de León, Jesús (con la colaboración de Manuel Gómez Portugal) “Apuntes para el estudio de la higiene de Aguascalientes", en VÁzquez del Mercado, 1892, pp. 177-248.

Eirale, Luis

"Informe sobre el cultivo de la vid en Aguascalientes", 18 de julio de 1888, en Informes y documentos relativos a comercio interior y exterior, agricultura, minería e industria, México, Secretaría de Fomento, núm. 38, agosto de 1888, pp. 3-4.

Epstein, Isidoro

Cuadro Sinóptico de Aguascalientes, Aguascalientes, Tipografía de Ávila y Chávez, 1861. 
Escalante Gonzalbo, Fernando

Ciudadanos imaginarios, México, El Colegio de México, 1992, pp. 97-100.

Escobedo, Francisco

"El pequeño riego en México", en Palerm Viqueira y MarTÍNEZ SALDAÑa, 1997, pp. 285-317.

EsPinoza, Rodrigo

Ligeros apuntes históricos, geográficos y estadísticos del estado de Aguascalientes, México, Oficina Tipográfica de la Secretaría de Fomento, 1900.

\section{Estadísticas}

Estadísticas históricas de México 2009, México, Instituto Nacional de Estadística y Geografía, 2010.

Fernández Ledesma, Enrique

"Aguascalientes, la ciudad de las flores, de los frutos y de las aguas", en Acevedo Escobedo, 1976, pp. 230-233.

Gómez Serrano, Jesús

Aguascalientes en la historia, 1786-1920, t. III, Sociedad y cultura, México, Gobierno del Estado de Aguascalientes, Instituto de Investigaciones Dr. José María Luis Mora, 1988.

"Isidoro Epstein y la difusión del positivismo en México", en Istor, 18 (otoño 2004), pp. 112-118.

"Una historia escrita con tinta de agua. La lucha por el control del agua en la villa de Aguascalientes durante los siglos xvil y xviII", en Miño Grijalva y Hurtado Hernández (coords.), 2005.

"Las huertas y la vid, el vino y el chinguirito en la villa de Aguascalientes a fines de la época virreinal”, en Estudios de Historia Novohispana, 48 (ene.-jun. 2013), pp. 123-187. 
González, Agustín R.

Historia del estado de Aguascalientes, México, Imprenta de A. Villada, 1881.

Guerra, François-Xavier

México: del Antiguo Régimen a la Revolución, México, Fondo de Cultura Económica, 1988.

Hernández Charro, María Carmen

"Agua y poblamiento. Notas sobre la configuración del territorio de Tudela Andalusí”, en Studia Historica, Historia Medieval, 24 (2006), pp. 315-339.

Herrera y Leyva, Pedro de

“Descripción de la subdelegación de Aguascalientes” (1794), en "Documentos antiguos relativos al estado de Aguascalientes”, en Boletín de la Sociedad Mexicana de Geografía y Estadística, segunda época, t. III (1871), pp. 17-25.

Hornedo, Francisco G.

Memoria que sobre los diversos ramos de la administración pública presenta a la Honorable Legislatura el ciudadano Francisco G. Hornedo, gobernador constitucional del Estado de Aguascalientes por el período del primero de diciembre de 1883 a 30 de noviembre de 1887, Aguascalientes, Imprenta de Trinidad Pedroza, 1887.

Hurtado Hernández, Édgar

“La ciudad sedienta, 1810-1910”, en Hurtado Hernández (coord.), 2011.

Hurtado Hernández, Édgar (coord.)

La ciudad ilustrada: sanidad, vigilancia y población, siglos XVIII y XIX, Zacatecas, Universidad Autónoma de Zacatecas, 2011. 
Krause, Corinne

Los judios en México. Una historia con énfasis especial en el periodo de 1857 a 1930, México, Universidad Iberoamericana, 1987.

Loyola Vera, Antonio

Sistemas hidráulicos en Santiago de Querétaro. Siglos XVI-XX, Querétaro, Gobierno del Estado de Querétaro, 1999.

Lozano Armendares, Teresa

El chinguirito vindicado: el contrabando de aguardiente de caña y la política colonial, México, Universidad Nacional Autónoma de México, 1995.

Madrid Alanís, Adolfo (dir.)

Manantiales, vida y desarrollo, siglos XVI-XX. Evolución de los sistemas de agua potable y alcantarillado de la ciudad de Aguascalientes, Aguascalientes, Comisión de Agua Potable y Alcantarillado del Municipio de Aguascalientes, 1995.

Martínez Delgado, Gerardo

Cambio y proyecto urbano. Aguascalientes, 1880-1914, Aguascalientes, Universidad Autónoma de Aguascalientes, 2009.

Martínez López, Heliodoro

El Aguascalientes que yo conocí, Aguascalientes, Imprenta de Daniel Méndez Acuña, 1977.

Martínez Saldaña, Tomás

La diáspora tlaxcalteca. Colonización agrícola del norte mexicano, Tlaxcala, Gobierno del Estado de Tlaxcala, 1998.

Mazzoni, Giuliana

¿Se puede creer a un testigo?, Madrid, Trotta, 2010. 
Meyer, Jean

La vitivinicultura en México. El caso de Aguascalientes, Zamora, El Colegio de Michoacán, 1985.

Miño Grijalva, Manuel y Édgar Hurtado Hernández (coords.)

Historia del agua: historiografía, tecnología, usos y conflictos por el agua, México, El Colegio de México, Universidad Autónoma de Zacatecas, 2005.

Mota y Escobar, Alonso de la

Descripción geográfica de los reinos de Nueva Galicia, Nueva Vizcaya y Nuevo León, México, Instituto Jalisciense de Antropología e Historia, 1966.

Orozco y Berra, Manuel

Materiales para una cartografía mexicana, México, Secretaría de Agricultura, Ganadería, Desarrollo Rural, Pesca y Alimentación, Mapoteca Manuel Orozco y Berra, 2012.

Ortega Douglas, Luis

Segundo Informe de Gobierno 1957-1958, Aguascalientes, Talleres Gráficos del Estado, 1958.

Tercer Informe de Gobierno, 1958-1959, Aguascalientes, Talleres Gráficos del Estado, 1959.

Ortiz Escamilla, Juan (coord.)

La transformación de los paisajes culturales en la cuenca del Tepalcatepec, Zamora, El Colegio de Michoacán, 2012.

Ortiz Garza, Nazario

Remembranzas. Visión de un luchador, México, Fundación de Investigaciones Sociales, 1991.

Palerm Viqueira, Jacinta y Tomás Martínez Saldaña

Antología sobre pequeño riego, vol. I, México, Colegio de Postgraduados, Plaza y Valdés, 1997. 
Antología sobre pequeño riego, vol. II, Organizaciones autogestivas, México, Colegio de Postgraduados, Plaza y Valdés, 2000.

Antología sobre pequeño riego, vol. III, Sistemas de riego no convencionales, México, Colegio de Postgraduados, 2002.

Pani, Arturo

Ayer, México, Stylo, 1954.

Pérez Arce, Salvador

"Ideas generales sobre un proyecto económico para proveer a la ciudad de Aguascalientes de una cantidad de agua para irrigaciones igual a la que suministra el manantial del Ojocaliente”, en Díaz de León, 1892, pp. 206-211.

Ramírez Hurtado, Luciano

"La apertura de la Avenida de la Convención y la continuidad del proyecto de modernización porfirista", en Caleidoscopio, 13 (ene.-jun. 2003), pp. 109, 111.

\section{Reglamento}

Reglamento de Regadios, reformado por el $\mathrm{H}$. Congreso del Estado, Aguascalientes, Tipografía del Gobierno a cargo de E. Parga, 1874.

Ribera Carbó, Eulalia

Herencia colonial y modernidad burguesa en un espacio urbano: el caso de Orizaba en el siglo XIX, México, Instituto de Investigaciones Dr. José María Luis Mora, 2002.

Rojas, Beatriz

"El cultivo de la vid y la fabricación de chinguirito", en Relaciones, 26 (primavera 1986), pp. 35-57.

Las instituciones de gobierno y la élite local. Aguascalientes del siglo XVII hasta la Independencia, México, El Colegio de Michoacán, Instituto de Investigaciones Dr. José María Luis Mora, 1998. 
Salas López, Carlos

Para la historia de Aguascalientes. Datos inéditos extractados de documentos auténticos por el Lic. Carlos A. Salas López, Aguascalientes, Folletín de La Prensa, 1919.

Salmerón Castro, Fernando

Intermediarios del progreso. Política y crecimiento urbano en Aguascalientes, México, Centro de Investigaciones y Estudios Superiores en Antropología Social, 1996.

SÁnchez Rodríguez, Martín

"Los pueblos huerteros de la cuenca del Tepalcatepec", en ORTiz Escamilla (coord.), 2012.

Sánchez Rodríguez, Martín y Evelyn Alfaro Rodríguez

"Notas para la historia de la horticultura y el autoabasto urbano en México", en Sociedad y Ambiente, año 1, 1: 2 (jul.oct. 2013), pp. 116-140.

Sánchez Rodríguez, Martín y Brigitte Boenm Schoendube

Cartografía hidránlica de Michoacán, Zamora, El Colegio de Michoacán, Gobierno del Estado de Michoacán, 2005.

Segura del Pino, Dolores

Agua, tierra y sociedad en el río de Almería: de la época islámica a la cristina, siglos XV y XVI, Almería, España, Diputación de Almería, Instituto de Estudios Almerienses, 2000.

Super, John C.

La vida en Querétaro durante la Colonia, 1531-1810, México, Fondo de Cultura Económica, 1983.

Topete del Valle, Alejandro

"La vid y el vino en Aguascalientes", cuadernillo publicado como apéndice de la tercera edición de Aguascalientes. Guía para visitar la ciudad y el estado, 1973, pp. i-ix. 
Efemérides aguascalentenses, publicadas en El Sol del Centro entre el $1^{\circ}$ de octubre de 1982 y el 30 de septiembre de 1983.

Vázquez del Mercado, Alejandro

Memoria que sobre los diversos ramos de la administración pública presenta a la Honorable Legislatura el ciudadano Alejandro Vázquez del Mercado, gobernador constitucional del Estado de Aguascalientes, por el periodo de $1^{\circ}$ de diciembre de 1887 a 30 de noviembre de 1891, Aguascalientes, Tipografía de J. Díaz de León a cargo de Ricardo Rodríguez Romo, 1892. 
